University of Louisville

ThinkIR: The University of Louisville's Institutional Repository

Electronic Theses and Dissertations

$6-1944$

\title{
A history of the financing of the Private Family Agency, Louisville, Kentucky.
}

Verna Schwab Will

University of Louisville

Follow this and additional works at: https://ir.library.louisville.edu/etd

Part of the Social Welfare Commons

\section{Recommended Citation}

Will, Verna Schwab, "A history of the financing of the Private Family Agency, Louisville, Kentucky." (1944). Electronic Theses and Dissertations. Paper 2186.

https://doi.org/10.18297/etd/2186

This Master's Thesis is brought to you for free and open access by ThinkIR: The University of Louisville's Institutional Repository. It has been accepted for inclusion in Electronic Theses and Dissertations by an authorized administrator of ThinkIR: The University of Louisville's Institutional Repository. This title appears here courtesy of the author, who has retained all other copyrights. For more information, please contact thinkir@louisville.edu. 
UNIVERSITY OF LOUISVILIE

A HISTORY OF THE FINANCING OF THE PRIVATE FAMILY AGENCY, LOUISVILLE, KENTUCKY

\author{
A Dissertation \\ Submitted to the Faculty \\ Of the Graduate School of the University of Loulsville \\ In Partial Fulfillment of the \\ Requirements for the Degree \\ of Master of Science in Social Administration
}

Division of Social Administration

By

VERNA SCHWAB WILL

Year

1944 
NAME OF STUDENT: Verna Schwab Will

TITLE OF THESIS: A History of the Financing of the Private Family Agency, Louisville, Kentucky.

APPROVED BY READING COMMITTEE COMPOSED OF THE FOLLOWING MEMBERS:

John J. Cronin

Annie Louise Pruitt

Guy Stevenson

NAME OF DIRECTOR: Mr. John J. Cronin

DATE: June 9/, 1944 


\section{ACKNOWLEDGMENT}

Appreciation is expressed to all persons who extended assistance in this study. Special acknowledgment is extended to Mr. John J. Cronin for his kind assistance and guidance; to Miss Esther M. Taylor for her suggestions and for her kindness in permitting examination of all the records of the Family Service Organization; to Mrs. Mabel Mason Ludwig for her assistance with the financlal figures of the agency; and to Miss Mary B. Stotsenburg for her helpfulness in providing material relative to the development of the Community Chest in Louisville, Kentucky. 
TABLE OF CONTENTS

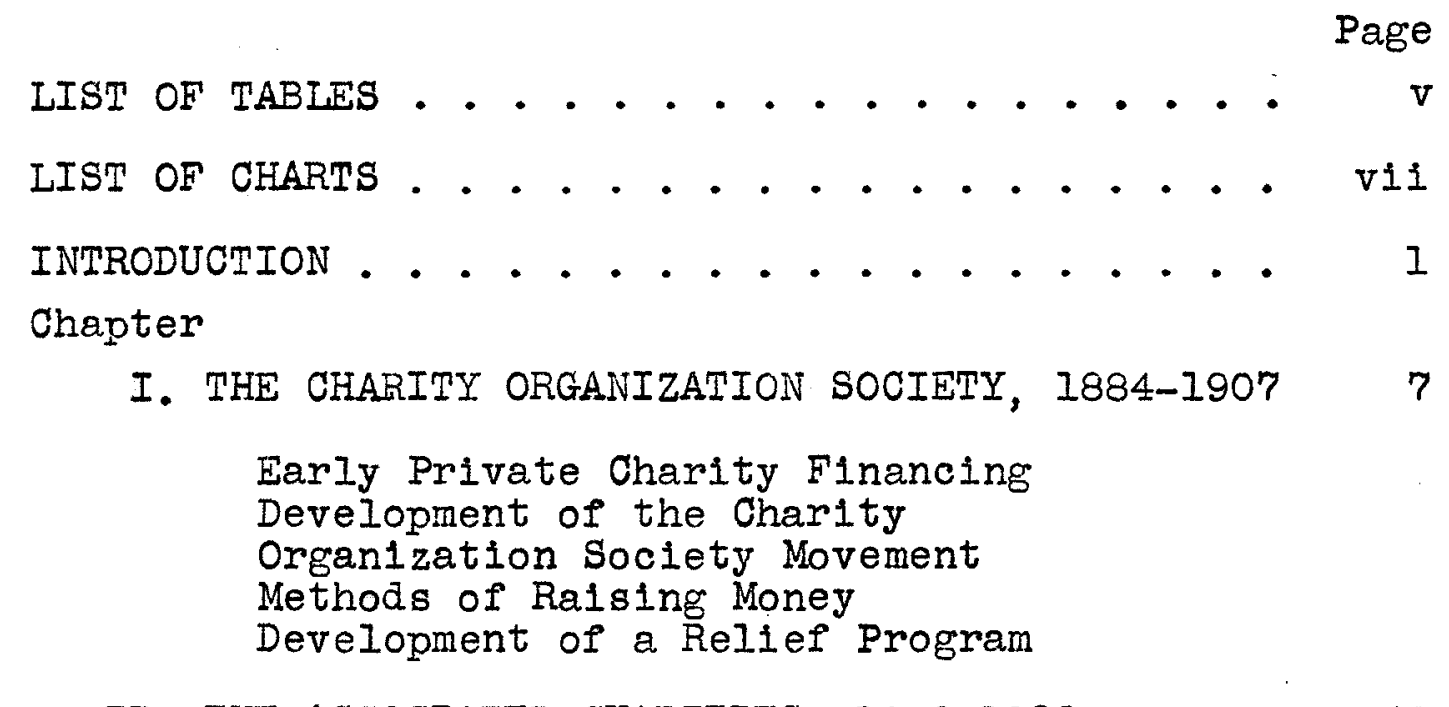

II. THE ASSOCIATED CHARITIES, 1908-1922 . . . 40

Period of Co-operation

Use of Palä Workers

Development of Federated Financing

Bookkeeping and Auditing of Books

Methods of Ralsing Money

III. THE FAMILY SERVICE ORGANIZATION, 1923-1928

69

Change in Emphasis - Preventive and Constructive Work

General Movement Toward Federation, Standardization, and Unification

Regulation of Bookkeeping and Budgeting

Preparation and Presentation of Budgets

IV. THE FAMILY SERVICE ORGANIZATION, 1929-1942

99

Period of Public Subsiay

Development of Public Relief Program

Period of Transition, 1939-1942

Re-definition of Function of the Agency

Publicity of a More Positive Nature

Special Funds 


\section{LIST OF TABLES}

Table

Page

1. Bushels of Coal Contributed by the City of

Louisville through the Charity

Organization Society, 1886 through 1906 . 17

2. Tornado Relief Funds . . . . . . . . 19

3. Cash Income of General, Emergency, and

Wayfarers' Lodge Funds of the Charity

Organization. Soclety, 1884 through 1907 . . 23

4. Contributors by Amount to Charity

Organization Society of Loulsvilie,

Kentucky, for 1885,1895 , and 1905 . . . 25

5. Expenditures for Relief and Other

Expenditures of the Charity Organization

Society of Loulsville, Kentucky, by

Amount and Percent, 1884 through 1907 . . . 31

6. Total Expenditures and Expenditures for

Salaries of the Charity Organization

Society of Loulsville, Kentucky, 1884

through 1907 . . . . . . . . . . .

7. Expenditures for Relief and Other

Expenditures of the Associated Charities

of Louisville, Kentucky, by Amount and

Percent, 1909 through 1922. . . . . . 48

8. Expenditures for Salaries of the

Associated Charities of Louisville,

Kentucky, by Amount and Percent, 1909

through 1922 . . . . . . . . . . .

9. Sources of Income of the Associated

Charities of Louisville, Kentucky,

1909 through $1922 . . . . . . . . .556$

10. Number of Contributors and Amount of

Contributions Under Federated Financing . 
11. Expenditures for Relief and Other Expenditures of The Family Service Organization of Louisville, Kentucky, by Amount and Percent, 1923 through 1928 ...

12. Mothers' Aid and Other Public Relief in Twelve Cities of the United States . . . 76

13. Salary Expenditures of The Family Service Organization of Louisvilie, Kentucky, by Amount and Percent, 1923 through 1928 . . 7 r

14. Sources of Income of The Family Service Organization of Loulsvilie, Kentucky, 1923 through 1928 . . . . . . . 78

15. 1925 Budget of The Family Service Organization as Submitted to the Communty Chest ............

16. Estimated Income of Family Service Organization for 1925 as shown in Budget Submitted to the Community Chest .....

17. Sources of Income of The Family Service Organization of Louisville, Kentucky, 1929 through 1942 . . . . . . . . .

18. Relief Expenditures and Other Expenditures of The Family Service Organization of Louisville, Kentucky, by Amount and Percent, 1929 through 1942 . . . . . . 120

19. Salary Expenditures of The Family Service Organization of Louisvilie, Kentucky, by Amount and Percent, 1929 through 1942 ... 123

20. Educational Qualifications of Workers of The Family Service Organization of Louisville, Kentucky, in 1929 and 1942 - 126

21. Budget of Expenditures of The Family Service Organization of Louisvilie, Kentucky, for 1944 as Presented to the Community Chest............ 128

22. Budget of Income of The Family Service Organization of Louisville, Kentucky, for 1944 as Presented to the Community Chest . 129

23. Total, Relief, and Salary Expenditures of The Family Service Organization for Every Tenth Year Beginning with 1893 


\section{IIST OF CHARTS}

Chart

Page

I. Expenditures for Relief and other

Expenditures of the Associated Charities of Louisvilie, by Amount, 1909 through 1922 $\cdot \cdot \cdot$

II. Sources of Income of the Associated Charities of Louisville, by Amount, 1909 through 1922

III. Expenditures for Relief and other

Expenditures of The Family Service

Organization of Louisville, Kentucky,

by Amount, 1923 through 1928......

IV. Sources of Income of The Family Service Organization of Louisvilie, Kentucky, 1923 through 1928 ...........

V. Sources of Income of The Family Service Organization of Louisville, Kentucky, 1929 through 1942 . . . . . . . . .

VI. ReIief Expenditures and Other Expenditures of The Family Service Organization of Loulsville, Kentucky, 1929 through 1942 . . . . . . . . . 121

VII. Total, Relief, and Salary Expenditures of The Family Service Organization for Every Tenth Year Beginning with 1893 
INTRODUCTION 


\section{INTRODUCTION}

Finances play an imoortant part in the operation of any business or organization. Quite often, it is a part that is little understood or studied except by the spectalists in the financlal fiela. A large proportion of the general public pays little more than a passing glance at the published financial papers of an organization. Particularly is this true of the welfare or social service organizations. Yet such agencies are usually the ones which come in for a greater share of criticism in connection with the expenditure of money. The purpose of this study, however, is not to attempt to answer specific criticism which might arise regarding the financial status or expenditures of the Family Service Organization; although it is hoped that by this history of the financial development of the agency, a better understanding may be secured. The presentation of certain figures of income and expenditures over a period of years will ald in giving a clearer plcture of the changes of the function of the agency, its services, and its financial needs since its incorporation to the present time, and how the agency has faced the needs of the people in each changing period.

This history is made as a companion to several 
other histories of the agency. These histories show that the development of the agency seems to fall into natural divisions. The agency was first known as the Charity Organization Soclety and was incorporated in 1884. In 1907, the name was changed to the Associated Charities. The agency became known as the Family Service Organization in 1921, and has kept this name until the present time. Within this period, however, there are certain natural divisions which have resulted from certain developments in the community which have affected the function of the agency. Each change of name reflected a change in philosophy or function of the agency. In this history, the periods of time are approximately the same although there may be a variation of a year or so, as it is understandable that a budget change would tend to occur after a change in philosophy or function.

Several reasons influenced this study. First, in order to complete the picture of the historical development of the Family Service Organization, a financial history was needed. A "History of the Family Service Organization" showing the general development of the agency had been written by Mrs. Bernice Ellis. "Lay Participation in the Private Family Agency, Louisville, Kentucky", written by Miss Mildred Bateman, showed the importance of the participation and support of interested citizens in the agency. "A Study of the Family Service Organiza- 
tion, Louisville, Kentucky, in Reference to Intake", by Miss Marian E. Prinz, showed the developing philosophy of intake by the agency through the years. Secondly, it was thought that it is of 1mportance to know the methods, the philosophy, and sources of obtaining money. Changes in these have occurred, no doubt, when general philosophies and ways of living have changed. How does our agency compare with the other private agencies throughout the country? of equal importance is the manner in which private agencies spend money. Money spent unwisely results in having fewer people interested and less money contributed. It is probably true that expenditures today will show a varlance with expenditures of fifty years ago. A financial study will ald in showing any changes in philosophy of case work and personnel standards.

Many questions naturally arise in regard to finances. Where does the agency get its money? For what purpose is it given? What part is used for relief? Who best can alspense it? These are a few questions which is hoped this study will answer.

Because of the importance of wise expenditures, it would seem a budget is a necessity. A budget is defined as a "financial forecast - planning the future of an organization in terms of the income which will be or must be made available, the expenditure which necessitates that income and the service which will require 
that expend1ture" -..- "A budget in the simplest terms is a plcture in dollars and cents of the service an agency expects to give during a future period."I Does the agency have such a financial plan?

It is felt that some definition of public and private agencies should be made since this study concerns itself primarily with the finances of a private agency.

By "public charities" it is meant those institutions or agencies which are entirely controlled by the State in any of its branches, federal, state, county, township or municipality. Public funds are such funds as are derived from the revenues of the State in any of its branches. They are usually proceeds of taxes.

Private charities are those that in their managements are independent of the authority of the State, although like private individuals they may be subject to his general police and supervisory powers. A private charity may receive public money in the form of a subsiay, or from proceeds of legacles or endowments, or from voluntary contributions. 2

Material for this study was taken from the Agency's annual reports, minutes of the Board of Directors from 1912 to the present, special studies made within the agency, press reports, and auditors' reports since 1914. Assistance was also secured from the three studies previously mentioned written by Mrs. Ell1s, Miss Prinz, and Miss Bateman.

\section{1}

Elwood Street, Soc1al Work Administration, (New York: Harper and Brothers, 1931), p. 357.

2 Amos G. Warner, American Charities, (New York: Thomas Y. CrowelI Co., 1919), p. 381. 
6

There were gaps in the materlal, and the figures of income and expenditures were not always accurate. This was true particularly in the early years of the agency. After 1914, when the books began to be audited, the figures were accurate.

Additional information was secured through interviews with Miss Esther Taylor, Executive Secretary of the Family Service Organization since 1930, and with Mrs. Mabel Mason Ludwig, Bookkeeper since 1922. Information regarding the Louisville Community Chest was secured from Miss Mary B. Stotsenburg, Executive Secretary of the Chest.

The approach to the study is from the historical point of view; although certain statistical data regarding the finances play an important part in this study. 
CHAPTER I

THE CHARITY ORGANIZATION SOCIETY, 1884-1807 
CHAPTER I

THE CHARITY ORGANIZATION SOCIETY, 1884-1907

Since the Family Service Organization is a private agency and this history is concerned primarily with the finances of the private society, it might be well to review briefly the early beginnings of private charity financing.

"Long before there was anything which remotely, resembled organized charity, people helped each other 'naturally' as friends and neighbors." I Assistance in cases of disaster, sickness, and death were met by mutual aid which was spontaneous. There was no official action or organized philanthropy needed, for people were among friends who came in and did what they could as a matter of course. Significant instances of this can be found In the early Christian Church, the medieval guilds, the pioneer communtty in America, and in isolated rural communities today. However, as there became an increase in the numbers in a group, the original solidarity broke down. The simple neighborliness was no longer sufficient, and there was need for supplementation by institu-

1

Stuart A. Queen, "Backgrounds of Social Work", Intelligent Philanthrooy, ed. by Ellsworth Faris, Ferris Laune, and Arthur J. Todd (Chicago: The University of Chicago Press, 1930), p. 245. 
tional care. This was the beginning of organized neighborliness. Here were seen also the beginnings of parish rellef when it was found necessary for chlidren to be supported at the expense of the church; whereas formerly the chllaren were taken in by neighbors. The influence of the church had always been one of the greatest factors in the securing of alms since ancient times. The merchant and craft guilds of the Midale Ages made contracts with hospitals for the care of their members and some guilds even went so far as to provide their own hospltals. In English and German cities, mayors provided food for citizens in times of famine. In addition to disaster relief and institutional care, the fifteenth and sixteenth centuries brought the development of aid to poor in their homes.

"Regulation of a Common Chest" drawn up by Luther in 1523 was the basis of widespread reform in Germany. Begging was prohibited, and all except the old and weak were required to work. If the poor in households "honorably" labored and had no support, loans without interest were given from the common chest. These loans could be given as gifts if the people were unable to return the money. "The income of the chest shall be composed of the revenues of eccleslastical estates, of free contributions, and, if necessary, of an assessment upon resident cltizens and a small poll tax upon ser- 
vants and journey men. Administration shall be in the hands of elected citizens."I

It can be seen that such a plan was a long way from the spontaneous mutual helpfulness. It was more than organized neighborliness. The power of the State was introduced to regulate begging; however, the repressive measures used to stamp out begging failed to accomplish their purpose. It was apparent that negative action was inadequate; so more positive measures were introduced. Local responsibility was fixed, taxes imposed, and the needy classified. The Poor Law of Elizabeth in 1601 laid the foundation for public rellef in England and America. There we found tax-supported institutions and agencies for service to persons with a variety of difficulties.

However, the public-supported institutions took care of only certain types of individuals, and it was necessary for private philanthrophy to continue. In the nineteenth century, there developed the charity by one social class extended to another soclal class as a result of the Industrial Revolution. A new middle class emerged due to the economic and social changes brought about by the factory system, growth of clties, 1ncreased mobility, and re-alignment of social classes. There fol-

1

William Ashley, Introduction to English Economic History, I, II, pp. 342-343, cited by Stuart A. Queen, 10id., p. 251 . 
lowed class conflict. Wealthy men sought political preferment through conspicuous philanthropies; their wives loved the sense of Importance derived from having poor families "under their wings" and the publicity from charity balls. Some found a "thrill in slumming", and some were genuinely sympathetic. This nineteenth century humanitarianism gave birth to a large number of relief societies which in turn gave rise to a great deal of confusion. Private almsgiving, mostly through organized and often incorporated societies, was profuse and chaotic. To meet the situation, first in England and then in America, there came into existence a group of agencles called the Charity Organization Socleties.

In America, conditions similiar to those in Europe had developed. However, in Amerlca, there was an abundance of free land and conditions of life were simple. There was no need for organized charity. Communities were small, men were neighbors, and the community resources met any need. There were some private or public charities, but these were restricted to a particular nationality or class of need. The first soclety concerned primarily with the problem of destitution was, as founded in 1817, the New York Soclety for the Prevention of Pauperism, later known as the Association for the Improvement of the Condition of the Poor. The winter of 1837-38 was a severe one in New York City. * Hasty, 1ll-advised rellef agencies which were set up, 
falled to meet the need. By 1840, there were over thirty relief societies in New York. They all showed "lack of discrimination in giving relief, lack of cooperation, fallure to establish personal intercourse with recipients of alms at their homes, and failure to relate their work to the existing public provision for the destitute." I Such conditions gave rise to the demand for a more comprehensive study and a well-considered attempt to grapple with poverty. Charity took on a new and broader outlook. As a result, the Association for the Improvement of the Conaition of the Poor of New York was born in 1840 .

Similar socleties grew up in other cities. Twenty years later, these societies themselves had become ineffective and were not meeting the needs of the community. The movement which had begun in the 1840's with such bright prospects had falled to fulfill expectations. They had fallen into routine methods and were simply relief societies.

The Charity Organization Society movement originated in London in 1868, and was introduced in the United States about ten years later. The first real Charity organization Society in the United States was incorporated in Buffalo in 1877. Other cities which followed Buffalo's

$I_{\text {Frank Dekker Watson, Charity Organization Society }}$ Movement in the United States, (New York: McMilian Co., 1922) p. 79. 
lead were Boston, New Haven, Philadelphia (1878), Cincinnati, Brooklyn, Indianapolis (1879), and New York City (1882). The purposes of these societies were generally the same. They included the correlation of work by other societies and repression of outdoor relief. No rellef was given by the Charity Organization Soclety, but the needy client was referred to possible sources of rellef. Methods included registration, investigation, friendly visiting, and co-operation with the policy to repress begging.

By 1883, there were approximately one hundred Charity Organization Soc1eties in the United States. Most of those were in the large cities east of the Mississippi and north of the Mason and Dixon line. Their standards of service varied. The Charity Organization Soclety of Loulsville was chartered on May 9, 1884, and was named after the parent society in London. As was characteristic of most of the other societies, the agency divided the c1ty into districts. That plan assigned each district to a church which was, at that time, an influential factor in securing financial relief. One advantage of districting was the promotion of the "spirit of neighborliness" as the district office became the meetIng place for those interested in social needs. The offices were nearer to the client, and the "iriendly visitors" were in a more intimate relation with reference to 
the families.

As there were already many relief-giving societies in the city, the Charity Organization Society placed its emphasis on prevention and endeavored to attack causes of poverty. No relief was given, put a "worthy" applicant was referred to some agency already dispensing relief.

The underlying principles of the Loulsville society were comparable with the fundamental principles of the Charity Organization Society movement in the United states. The agency was not affiliated with any political, religious, or national group. It saw the need for co-ordinating the existing charitable agencies, and attempted to prevent the duplication of relief by the investigation of persons who applied for help. After an investigation of an application was made, a full report was given to the persons or societies who had been solicited. No charge was made by the society for such investigation. An attempt was made to secure adequate rellef for famllies where needed. Attempts were made to secure work for those able to become self-supporting. The governing body of the soclety was called the Central Council, the members of which donated their time and services. Like most of the other socleties in the country, the work was carried on by a general secretary with experienced agents in charge of the districts. The 
secretary and agents were the only paid workers. Actual visiting was done by the "Priendly visitors" who were residents of the district in which they worked.

In the beginning years of the Charity Organlzation Society, the work was limited and, as a result, a great deal of money was not needed. The salaries of the general secretary and the two paid agents, and the cost of maintaining the two offices were the only expenses. There originally were three alstricts, but the expense was too great. It was found that the work could be done with two districts. The funds received were pald to a financial secretary who made monthly reports to the Central Council of all sums received. Funds were then transferred to a treasurer. At flrst, all the money recelved went into the General Fund, which was used to defray the three salaries and expenses of the offices.

However, in adiltion to the money which was raised for the general expenses, contributions in the way of cash, coal, clothing, food, and other goods began to be recelved by the Society. Since the function of the agency did not include the dispensing of relief, those gifts were turned over to some benevolent society or church which gave relief and to which investigated families were referred if found "worthy".

During the second year of 1ts existence, the Charity Organization Society was put to "a test" by the 
c1ty. In January, 1886, the Mayor and the City Council provided 15,000 bushels of coal for those in need. The coal was given indiscriminately, and in ten days, the supply was exhausted. During the latter part of January, another 10,000 bushels were donated, and this time the coal was distributed through the Charity Organization Society on the recommendation of the agency's visitors. Two months of severe weather followed with three more months when fire was needed. Up until October I (an elght-month period), only 6,000 bushels had been used, and it was claimed by the Society that no one had suffered. The Charity Organization Society had passed 1ts first "test" successfully. This was the Soclety's first public subsidy. Other subsidies by the city in the form of coal were made in succeeding years. It is possible, in the light of history, to ascertain from the data in Table 1, the outstanding events which took place during the period by the amount of subsidies made by the city. The winter of 1893-94 followed the panic in the summer of 1893 which brought ruin to many large establishments. Hundreds of employees were out of work. The winter of 1894-95 was of unusual length and severity, and followed the great commercial depression from which many had not yet recovered. It would indicate that very little public responsibility had been assumed until it was absolutely necessary, and there were no other means with which to meet the needs. 
As the Society had proved the value of its

methods of investigation and registration in dispensing the coal, the Charity Organization Society was called in at once, as investigators, when the tornado struck the c1ty in March, 1890. The Board of Trade appointed ten people as a Relief Committee of the Board of Trade. This

\section{TABLE 1}

BUSHELS OF COAL CONTRIBUTED BY THE CITY OF LOUISVILIEE THROUGH THE CHARITY ORGANIZATION SOCIETY,

\section{THROUGH 1906}

Year

Bushels

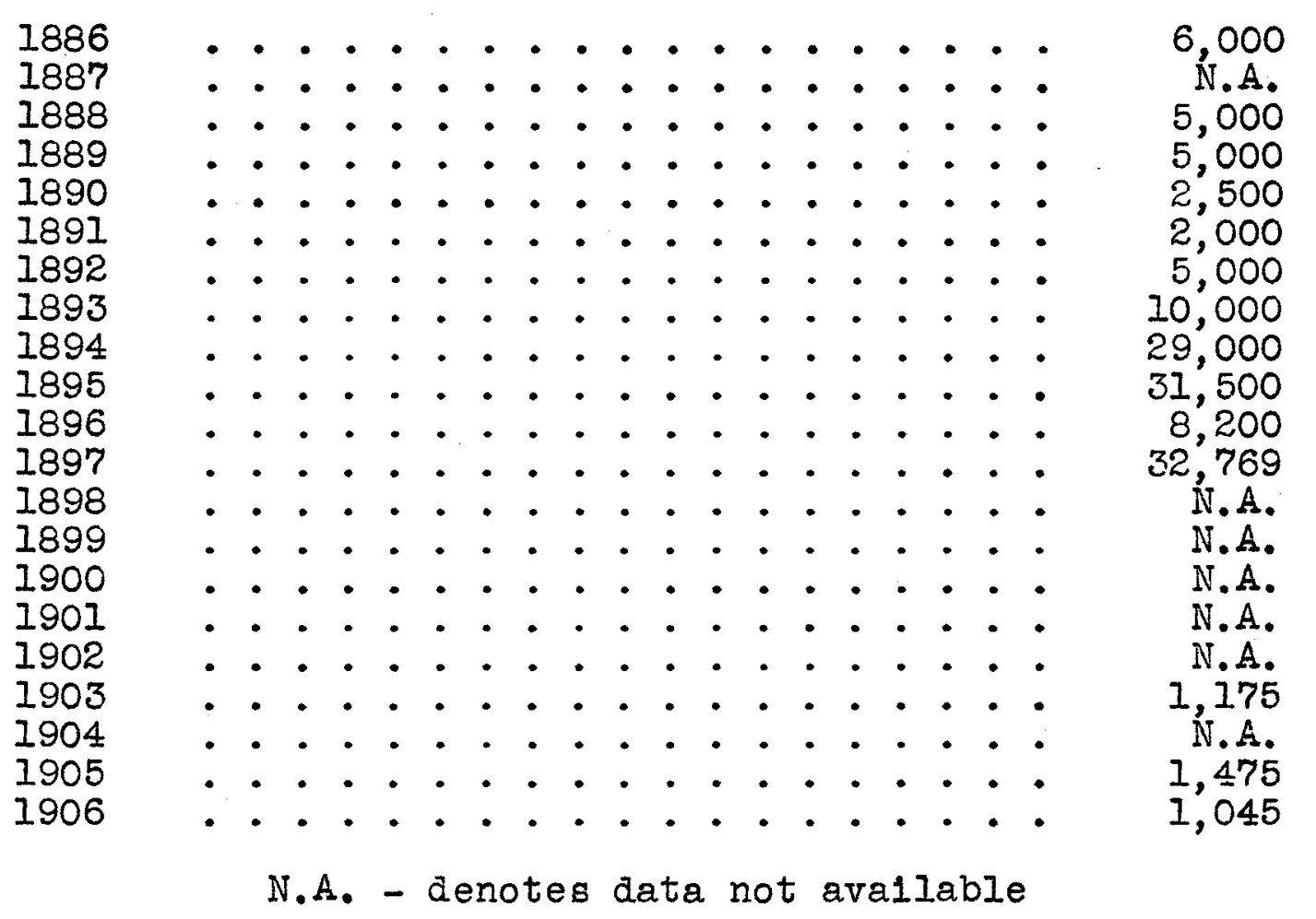

committee utilized the Society's visitors as investigators 
who were assisted by voluntary investigators from c1t1zens, members of the Board of Trade, and other civic organizations. A permanent relief committee was formed whose duty was to see all friends and relatives of the injured and dead. The injured were taken to homes, hospitals, and institutions. Expenses were paid for those unable to pay for the required care. Financial assistance was given to persons dependent upon an incapacitated wage earner in amounts varying from twenty to thirty dollars per month for eighteen months. Similar sums were paid from three to twelve months for the permanently injured, and permanent funds were established to provide care for the dependents of wage earners who were kllled. The expenses of burlal and medical care were paid. Three hundred eleven homes were re-built at a cost of $\$ 71,435.59$. Furniture was supplied to replace that which had been lost. No attempts were made to compensate for the loss of merchandise. It was held that mercantile losses were beyond the Committee's province and the funds given as charity were not intended for such use. Table 2 indicates the source and amount of relief funds.

Twenty thousand dollars were returned to the City after having pala the losses in full. A small balance remained in the General Rellef Fund of the Board of Trade for future calamities. In less than fifty days, losses were restored, homes re-bullt, and the books closed; all due to the systematic organization for which the Louis- 
ville Charity Organization Soclety received the credit.

TABLE 2

TORNADO RELIEF FUNDS

Source of Funds

Total

Legislature of the State

Council of City of Louisville

Voluntary subscriptions

outside the State

Voluntary subscriptions

by citizens of Louisvilie
Amount

$\$ 156,045.76$

$5,000.00$

$20,000.00$

$15,547.05$

$115,498.71$

In keeping with the general philosophy throughout the country at the time, the Louisville Charity Organization Society was not very sympathetic or tolerant with regard to vagrants and the "unworthy" unemployed. Before the end of the second year, there was established under the auspices of the Society a Wayfarers' Lodge. The funds for the establishment of that endeavor amounted to $\$ 2,663.40$, and were raised by popular subscription. The purpose of the Lodge was to provide meals and lodging in return for work in the wood yard. It was also used as a "labor test" for the unemployed. The motto of the Wayfarers' Lodge was "If a man w1Il not work, neither shall he eat." The kindling wood cut in the wood yard, in return for a night's lodging and food for a day, was sold. The money recelved from the sale was used for expenses 
of the Lodge. This money was kept separately and was not included in the General Fund of the Charity Organization Soclety. During the period from 1884 to 1907, the Wayfarer' ' Lodge was entirely self-sustaining. The money from the sale of the kinding was adequate to defray the necessary expenses.

As has been previously stated, the purpose of the Charity Organization Society was not to dispense alms. From the beginning, contributions in cash, coal, food, and clothing were constantly being given to the Soclety. Although a record of the amount was kept, these were turned over to benevolent societies whose function was that of alms-giving. None of the contributions were entered with the General Fund for the operation of the agency. It was soon discovered, that in many coses emergency assistance was needed whlle investigation was being made. The soclety could not consclentiously refer a famiIy to a benevolent society until the investigation was completed, and many times, a family suffered while the investigation was being made. To alleviate this interim suffering, the Charity Organization Society established an emergency fund in 1890. That fund was under the control of the Secretary and a Commlttee of the Council. The money contributed to that fund did not go into the funds of the Society, but was used solely and exclusively in relleving the pressing and immediate wants of those in distress. In 1892, a benevolent committee of the Society 
was formed whose duty was that of raising funds for emergency cases. The donors were assured that the money would be used to relleve actual want.

The experience of the oldest workers in charity has taught that an organization soclety should not dispense alms, first because its work of rellef is in a direction not covered by any other soclety and is, in 1tself, as much as should be undertaken, and second because it interferes with its true work and injures its influence with strictly benevolent socleties, of which there are many. For these reasons, we have consistently avoided making the soclety a dispenser of alms. But because of the frequent cases requiring relief pending investigation, called emergency cases, the lack of a benevolent society organized to relleve without regard to race, sect, or condition......... we have appointed a Benevolent Committee with power to act. This committee receives all money sent to this soclety for relief purposes... The money is not co-mingled with that of the Society and is used as directed by the donor. 1

It is interesting to note that during the severe winter of 1892-93, people, without solicitation, sent money for the relief of distress until they were notified that no more was needed.

That plan was followed for a couple of years, but it was soon discovered that there was great confusion on the part of the contributors as to the money for the work of the soclety and the money for emergency rellef. Accoraingly, in 1895, it was decided to consolidate reports and show one list for all monetary contributions. A separate account was kept as to the specific requests

$I_{\text {Annual Report, }} 1894$. 
of the donors so that such money given for emergency relief or special families would be used for such purposes.

In 1893, Mary Richardson Belknap conveyed the real estate at 215 East Walnut Street to the organization as a memorlal to her husband, Wliliam B. Belknap. In the same year, R. A. Robinson contributed $\$ 5,000.00$ for the erection of the Wayfarers' Lodge to be built on the rear of the Belknap lot.

Table 3 shows the actual amount of the income in money in the various funds during the period 1884 through 1907. With the exception of the sale of kindling wood, which was used to defray the expenses of the Wayfarers' Lodge, the income was practically entirely received from subscriptions. A large part of the money received in the emergency fund was for the purchase of coal. It w1ll be noted that the income did not vary a great deal except for the depression years of 1893 to 1897, when 1t considerably increased. Figures were not available for some of the years. After 1897, the funds of the Emergency Fund and General Fund were merged. No explanation was found for the $\$ 34.7 I$ in the Emergency Fund in 1907. As most of the money was received through voluntary subscriptions, it was important to keep the public educated as to the nature of the work of the agency. One of the distinctive features of the Charity Organization Society throughout the country at that time was the 
CASH INCOME OF GENERAI, EMERGENCY, AND WAYFARERS' LODGE FUNDS OF THE CHARITY ORGANIZATION SOCIETY, 1884 THROUGH 1907

\begin{tabular}{|c|c|c|c|c|}
\hline Year & Total & $\begin{array}{c}\text { General } \\
\text { Fund }\end{array}$ & $\begin{array}{l}\text { Emergency } \\
\text { Fund }\end{array}$ & $\begin{array}{l}\text { Wayfarers' } \\
\text { Lodge Fund }\end{array}$ \\
\hline $\begin{array}{l}1884 \\
1885 \\
1886 \\
1887 \\
1888 \\
1889 \\
1890 \\
1891 \\
1892 \\
1893 \\
1894 \\
1895 \\
1896 \\
1897 \\
1898 \\
1899 \\
1900 \\
1901 \\
1902 \\
1903 \\
1904 \\
1905 \\
1906 \\
1907\end{array}$ & $\begin{array}{c}\$ 3,030.00 \\
3,783.51 \\
3,669.92 \\
4,672.40 \\
5,961.10 \\
4,896.00 \\
5,941.91 \\
5,681.40 \\
6,022.34 \\
7,972.61 \\
9,298.81 \\
8,727.89 \\
7,082.96 \\
8,171.87 \\
\text { N.A. } \\
\text { N.A. } \\
\text { N.A. } \\
\text { N.A. } \\
\text { N.A. } \\
5,921.45 \\
\text { N.A. } \\
\text { 5,744.15 } \\
5,320.15 \\
5,126.81\end{array}$ & $\begin{array}{c}\$ 3,030.00 \\
3,244.40 \\
3,181.92 \\
2,494.50 \\
2,822.50 \\
2,703.75 \\
2,927.00 \\
2,705.00 \\
2,719.25 \\
2,439.00 \\
3,988.50 \\
4,370.03 \\
2,984.96 \\
4,281.87 \\
\mathbb{N} . A . \\
\text { N.A. } \\
\text { N.A. } \\
\text { N.A. } \\
\text { N.A. } \\
3,298.15 \\
\text { N.A. } \\
\text { 3, 385.00 } \\
2,796.40 \\
3,103.45\end{array}$ & $\begin{array}{r}0.00 \\
539.11 \\
488.00 \\
802.75 \\
1,353.25 \\
338.00 \\
526.75 \\
552.00 \\
580.34 \\
2,352.51 \\
1,436.13 \\
206.81 \\
20.00 \\
20.00 \\
0.00 \\
0.00 \\
0.00 \\
0.00 \\
0.00 \\
0.00 \\
0.00 \\
0.00 \\
0.00 \\
34.71\end{array}$ & $\begin{array}{r}0.00 \\
0.00 \\
0.00 \\
1,375.15 \\
1,785.35 \\
1,854.25 \\
2,488.06 \\
2,423.50 \\
2,722.75 \\
3,181.10 \\
3,874.18 \\
4,151.05 \\
4,078.00 \\
3,870.00 \\
\text { N.A. } \\
\text { N.A. } \\
\text { N.A. } \\
\text { N.A. } \\
\text { N.A. } \\
2,623.30 \\
\text { N.A. } \\
2,359.15 \\
2,523.75 \\
1,988.55\end{array}$ \\
\hline
\end{tabular}


use of the "case by case method". In this method, a specific family was discussed. Money for that family was raised from individuals or societies interested in them. In this way, the actual and potential rellef found in every community was utilized. It also had the advantage of strengthening family ties and neighborhood duties. In the Loulsville Society, case conferences were held weekly. In these meetings, residents of the districts discussed treatment plans for selected families. The participants offered different points of view. The experience and thinking of the group was an asset to the early method of diagnosis. This not only aided the workers but also was a means of informing the public of poverty and the treatment of social problems by the use of the case method.

One of the outstanding methods of informing the public of the work of the Soclety during that period was the publication of the "Annual Report." That pamphlet usually contained a brief explanation of the purposes and objectives of the Society, a brief explanation of the type of work the agency had accomplished and what It expected to accomplish, a financial statement of income and expenditures of the various funds of the agency, several significant case stories, and at the end, a complete list of the membership for the year with the amounts contributed by each member. The contributions ranged from one dollar to over one hundred dollars as 
is pointed out in Table 4.

\section{TABLE 4}

\section{CONTRIBUTORS BY AMOUNT TO CHARITY ORGANIZATION SOCIETY OF LOUISVILLE, KY., FOR 1885,1895 , AND 1905}

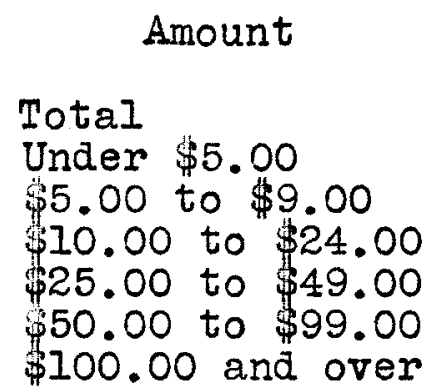

1885 1895 1905

Total

Under $\$ 5.00$ $\$ 5.00$ to $\$ 9.00$

$\$ 10.00$ to $\$ 24.00$

$\$ 25.00$ to $\$ 49.00$

$\$ 50.00$ to $\$ 99.00$

$\$ 100.00$ and over

$\begin{array}{rrr}187 & 278 & 268 \\ 8 & 27 & 30 \\ 94 & 75 & 98 \\ 41 & 106 & 96 \\ 27 & 45 & 28 \\ 14 & 19 & 12 \\ 3 & 6 & 4\end{array}$

Although there was some increase in the number of contributions from 1885 to 1895 , this was probably due to the fact that the year 1885 was the first year the number and names of contributors were published. Since the society was not well known, it can be seen that the number of contributors was not very large throughout the entire period. Generally, the names of the contributors were the same from year to year. The income of the Society appeared to rest largely on the gifts of a few interested and constant members. The names of those contributing baskets of food, packages of clothing, or other gifts in kind were contained in the list of subscribers.

Interpretation was greatly facilitated by the work of the Publication Committee, which was particularly active during the first year. 
To carry out its duty of acquainting the people of the city with the aims of the organization, the committee had printed and distributed a large number of forms, pamphlets, and circulars, the most important of which were: "Objects of the Soclety"; "Constitution and By-Laws"; "Rules for District Committees"; "Duties of Vis1tors to the Poor"; "Hints to Friendiy Visiting" ; notices to employers and pads of investigation tickets. On June 1, 1885, the Publication Committee had re-printed and gave wide distribution to a speech by Robert Treat Paine, Jr., Esq., President of the Boston Associated Charities, entitled "How to Repress Pauperism and Street Begging." The committee continually attempted by personal contacts to increase the membership of the society. 1

The newspapers were a very important medium of publicity and hence a means of securing subscribers. "The detail with which announcements of the work of the Society were reported and the editorial support of the principles and activities of the organization are evidence of confidence in the large group of laymen who were so actively engaged in the work. " 2

A great deal of general publicity was given in the press in connection with beggars, vagrants, and Prauds, which the Society succeeded in bringing to light. The articles were written to appeal more or less to the public's feelings of sympathy and pity for those who were "worthy" and feelings of resentment toward the "frauds"

$I_{\text {Mildred }} E$. Bateman, Lay Participation in the Private Family Acency, Louisvilie, Kentucky, (UnpubI1shed Master's thesis, University of Louisville, 1941), p. 34 .

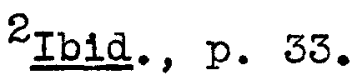


and professional beggars. In general, the approach was

to the emotions of the public.

Typlcal of an article of the period is the fol-

lowing:

That this organization is taking deep hold of the people in this country and Europe cannot be doubted. There are now thirty-six societies in the principal cities of the United States, and to show the importance, as well as the scope from which co-operation and assistance is obtained, and the interest that each soclety bears to one another, we quote the following, received in reply to a communication sent by this Society in the interest of a well-connected Kentucky family, reduced in circumstances through misfortune, who left this State for New York City, expecting, as nearly all strangers to a c1ty do, to find work without any trouble, but were mistaken and could get no work - money all expended and starvation facing them.

The Louisville Charity Organization Soclety was appealed to and had the Soclety in New York interest themselves in their behalf, with the result that immediately the family was visited and referred to several socleties and persons who make a particular business of obtaining employment for such as they - intelligent but needy women.

One is engaged presently with a wealthy lady; another will be placed in a class to learn typewriting; and the mother will be able to help a little with sewing.

All interested in the success of the Society in Louisville and having the welfare of the poor of this city at heart, are asked to co-operate and to assist in the good work. Inveatigation tickets headed "Give Nothing to Beggars" are being put into the hands of the public as quickly as possible, and if they will only do as asked by sending applicants to the district office for investigation, vagrancy, impostors, frauds, and begging will soon be stopped. Such classes will either be required to go to honest labor or else go to the Char1ty Organization Society to be properly dealt with. An employment bureau has been opened for those able to work that apply for charity. Persons in want of labor of any kind will be doing the poor a good turn by helping 
this Society in its efforts to make all able-bodied self-supporting, and thus avold the degrading tendency that almsgiving has for the recipients. Employers would do well to give this Soclety all the assistance they can to 1111 up vacancies, temporary or permanent. 1

Very often the articles were quite melodramatic

In character as is noted by the following article:

Some sharp swindlers are occasionally caught up with by the Louisville Charity Organization Society and pointed out to the police..... One is a respectable looking old farmer, who has been accompanied on his rounds by his son, twelve years of age. The old man told a plausible story about his wanderings away from home county and his pitiful condition.

To establish his character as being a worthy object of charity, he had among the signatures on his card the name of and a certificate from Col. showing that he had been with his regiment during the war and was a good Union soldier. Thus equipped, he managed to pick up a good many dollars until the Charity Organization Soclety investigated his case.

It was discovered that the man was a swindler of the first water. He owned a large farm in Breckinridge County and during his absence on his begging expeditions, the place was worked by his wife and three grown sons. The family was in very affluent circumstances, and it is thought that the old man's appeals to charity were prompted simply by his miserly greed.

In striking contrast to the above comes a pathetic Iittle story from a house of poverty and squalor, and a bed of sickness and death, told by one of the lady visitors of the Organization. A poor Italian woman had for a long time been 111 and suffering. Her little children, the eldest $s i x$ years old, were playing in the hall. The mother was very 111, and the end of her checkered Iife was fast drawing near. The chilaren were making a dreadful

${ }^{I}$ Courier-Journal, June 22, 1884. 
noise in the hall, and the mother raised her hand to quiet the children. The noise continued, and in a fretful and stern tone, the sick woman called the eldest girl to her. Everyone expected to see the mother strike the child, but instead this was the correction, "Natalie, who loves mama?" The answer was a loving, childish hug from the little girl. When her arms were taken from around her mother's neck, the woman was dead. ${ }^{1}$

In addition to the above articles which definitely kept the public informed of the work of the organization, stressing the value of investigation and registration, each Sunday there was published a column entitled "Charity Organization Society Notes." In that column, the various meetings and time of meetings of the districts and committees were listed for the following week. While these in themselves did not present an appeal for funds or present any interpretation of the Society's work, it showed an interest on the part of the press in the approval of the work of the organization. Such 1tems also kept the operations of the Society before the public.

On several occasions in the $1890^{\prime} \mathrm{s}$, the funds for emergency relief pending investigation were found to be inadequate. At such times, a direct appeal was made through the newspapers in the form of an open letter to the public. An example of such an open letter is as follows: 


\section{Citizens, Attention}

The Louisville Charity Organization Society is in Urgent Need of Funds. Loulsville, Kentucky, January 19, 1895, To the Citizens of Louisville: The Louisville Charity Organization Society is in urgent need of funds, both for its general work and its emergency fund, and unless funds are at once subscribed, this latter branch of our work must suspend its operations. If the public would take the trouble to call and see the workings of our Society at its offices, 221 East Walnut street, and the Wayfarers' Lodge, a much better 1dea of our work and its usefullness could be seen, and, we believe, appreclated. We dislike to put ourselves in the position of begging for funds, as we had hoped that the work we have performed in this line was a guarantee of support. We ask respectfully and urgently that subscriptions be sent to our Financial Secretary, $M r$.

Signed for the Louisvilie Charity Organization Society,

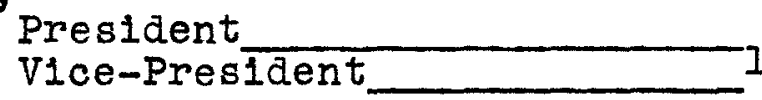

Because the services of the Society were limited, the expenses and therefore the income needed were fairly constant during the period. Table 5 shows the total amount of expenses, rellef expenses, and other expenses for each year of the period, with the exception of the years 1898 through 1902 and the year 1904, for which years the flgures were not available. In compiling the figures, 1t was noted that frequently the total of the items did not equal the total given. It is not known whether the discrepancies were typographical errors or clerical mistakes. The irregularities occasionally

$$
\text { I Ib1d., January 19, } 1895 .
$$


TABLE 5

\begin{abstract}
EXPENDITURES FOR RELIEF AND OTHER EXPENDITURES OF THE CHARITY ORGANIZATION SOCIETY OF LOUISVILIE, KENTUCKY, BY AMOUNT AND PERCENT, 1884 THROUGH 1907
\end{abstract}

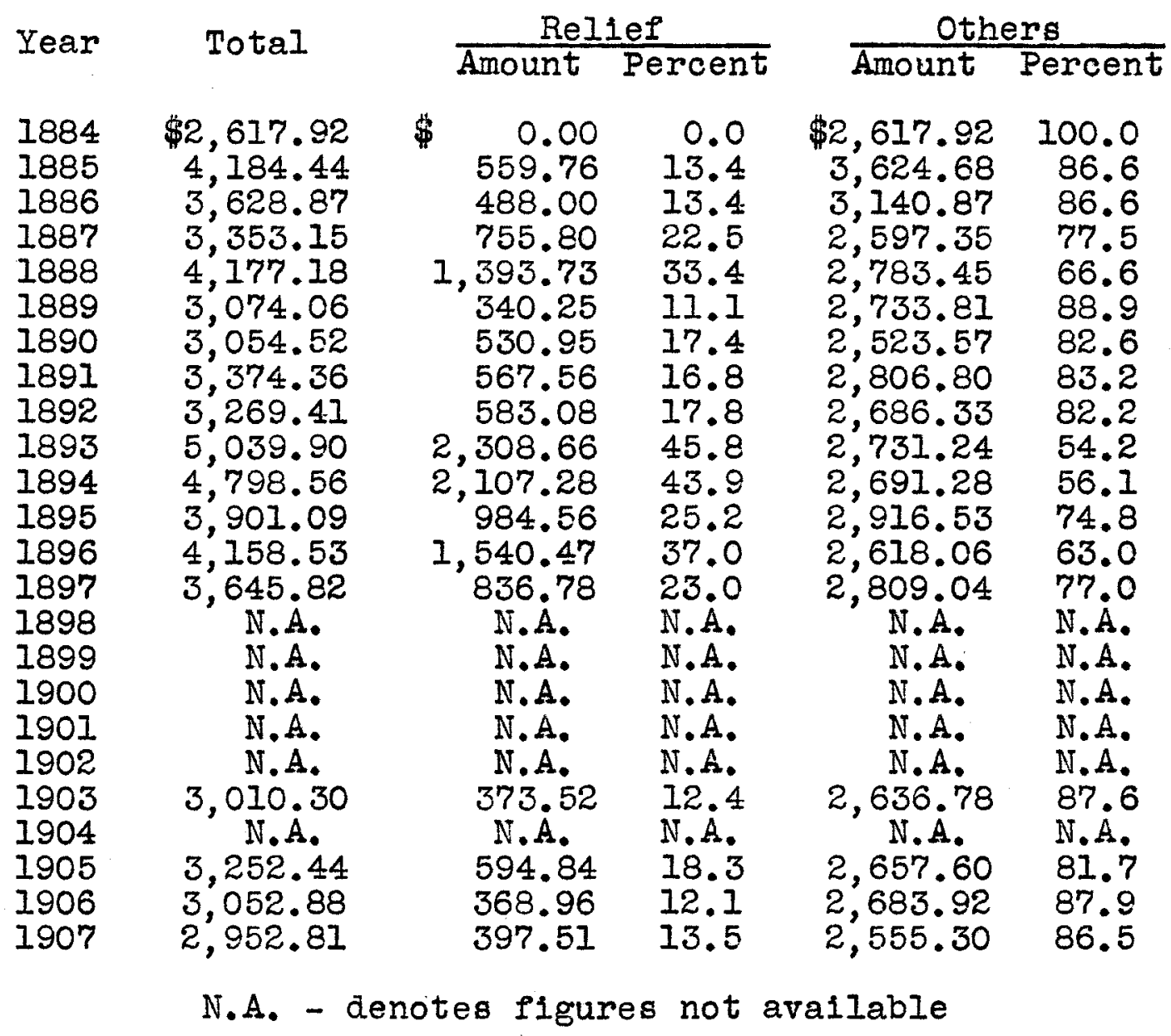


noticed in the bookkeeping of the Society were apparently general with all agencies in the country. It seems rather odd that outstanding men in the community would allow such discrepancies to go unnoticed when, no doubt, they were very particular about such things in their own businesses. It was probably due to the fact, however, that it was not a practice throughout the country for books to be audited, and the busy business men who donated their services did not have the time to check minutely the books and printing.

In compiling the figures for Table 5, the expenditures of the General Fund used for the operation and services of the Society were combined with the expenditures of the Emergency Fund in order to give the total amount. Until 1891, all the money in the Emergency Fund was not dispensed by the Soclety, but was turned over to some benevolent society. However, since the money did pass through the agency and was ultimately used for rellef purposes, it was considered as part of the expenditures of the Society. None of these figures included the expenses of the Wayfarers' Lodge. Although the alm originally, like all the Charity Organization Societies in the country, was not to dispense relief, it was impossible to carry on the work without giving some rellef. "By 1904, one-half of the Charlty Organization Socleties in the country were giving rellef from their own funds. Of 
the remalning half, some gave rellef in emergencles and some were the regular channel for such relief." ${ }^{1}$

Table 5 shows that, with the exception of the year 1885, the expenditures other than for relief were substantlally constant. In 1907, twenty-three years after the incorporation of the Society, those expenditures were $\$ 62.62$ less than the first year. The variation in relief expenditures was more marked, showing a peak in the depression years of 1893 and 1894. The varlation in the relief expenditures naturally affected the total expenditures. A marked relationship existed between relief expenditures and total expenditures; this is understandable as the other expenditures remained fairly constant during the period.

Although the Society was not a relief society, Table 5 reveals that, with the exception of the first year, some rellef was given. In keeping with the policy of not dispensing alms, the percentage of relief to the total expenditures was fairly small, with the exception of the depression years of 1893 to 1897. The peak years were 1893 and 1894 when the relief expenditures reached almost fifty percent of the Society's total expenditures. By 1907, rellef-giving had become a fairly well estabIished feature of the Society; although the figures show

$I_{\text {Frank Dekker Watson, Charity Organization So- }}$ clety Movement in the United States, (New York: McMilian Co., 1922), p. 168 . 
that only a small percentage was used for actual relief whlle the major portion of total expenditures were used for service for the families under its care.

As the Society was organized solely as a service society, it is not surprising that a large percentage of its total expenditures was for salaries, as is show in Table 6. Throughout the period of the Charity Organization Society, the only salaried employees were the General Secretary and the district agents. The Central Council and the District Conference members, all composed of members of the community, donated their time. The visiting was carried on by the "friendly visitors" who were also members of the community and usually residents of the district in which they worked. These "friendly visitors" were volunteers who donated their services. The emphasis of the work they did was more on helping families with their troubles rather than the giving of relief. The personal relationship between the family and the friendly visitor was stressed. The aim of the visitor was to provide a "friena" for each family. The friendly visitors:

exercise oversight over the family as to induce It to look up and out, to be hopeful and thrifty and self-supporting... Prevention of habits of dissipation, 1dleness and improvidence is the practical cure of pauperism. We do not see how this prevention can be attained except by means of friendly visttors and frequent conferences. 1

$I_{\text {Annual Report, }} 1887$. 


\title{
TABLE 6
}

\begin{abstract}
TOTAI EXPENDITURES AND EXPENDITURES FOR SALARIES OF THE CHARITY ORGANIZATION SOCIETY OF IOUISVILIE, KENTUCKY, 1884 THROUGH 1907
\end{abstract}

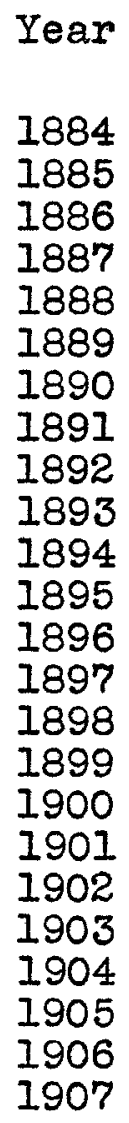

Total

$\$ 2,617.92$

$4,184.44$

$3,628.87$

$3,353.15$

$4,177.18$

$3,074.06$

$3,054.52$

$3,374.36$

$3,269.41$

$5,039.90$

$4,798.56$

$3,901.09$

$4,158.53$

$3,645.82$

N.A.

N.A.

N.A.

N.A.

N.A.

$3,010.30$ N.A.

$3,252.44$

$3,052.88$

$2,952.81$

Salaries

Amount

\$N.A.

$2,578.35$

$2,079.25$

$1,857.15$

$1,970.85$

$1,966.35$

$1,782.00$

$2,046.00$

$1,947.20$

$2,131.00$

$2,194.00$

$2,064.50$

$2,164.00$

$2,338.00$

N.A.

N.A.

N.A.

N.A.

N.A.

$2,236.00$

N.A.

$2,366.00$

$2,321.00$

$2,144.00$
Percent

N. A.

61.6

57.3

55.4

47.2

63.9

58.3

60.6

59.6

42.3

45.7

52.9

52.0

64.1

N.A.

N.A.

N.A.

N.A.

N.A.

74.3

N.A.

72.4

76.0

72.0

N.A. - denotes figures not avaliable 
The poor need other kind of help more than alms. That kfnd of help we give - and no one else gives. 1

The experlence during the early years of the Society revealed that to increase the effectiveness of the v1sitors' work and the work of the Society, some type of organized conference among the visitors should be created. However, no success resulted from the attempts made to accomplish that purpose.

All efforts at an organized force of visi-
tors, important as it is, has so far proved a
signal failure. It is necessary to rely upon
benevolent individuals wherever they could be
found disposed to take care of the individual
cases, but the supply has been fairly up to
the demand.?

Organization among the visitors was not possible at that time; although it was recognized that these untrained, unpald visitors allowed sympathy to rule and, often, by unwise giving, did more harm than good. The need for trained workers became more and more apparent. The trained charity worker saw a greater need than that of relief. "The uneducated, Inexperienced worker only sees in charity that which feeds and clothes the body." 3 By 1900, training schools began to arise simultaneously all over the country, and the need for pald, trained workers was seen. In 1900, in sixty-nine re-

\section{Ibid., 1890. \\ 2Ibid.}

3 Proceedings of the Conference of Charities and Corrections, 1900, p. 254. 
porting socleties, there were one hundred seventy-one pald workers. The Louisville Society was keenly aware of this need, but efforts to obtain trained workers were unsuccessful.

In the year 1907, in keeping with the trend throughout the country, the name of the Loulsvile Charity Organization Society was changed to the Louisville Associated Charities. This new title carried with it the idea of the organization of charities which the agency wished to convey.

In summary, private charity financing developed from the early, spontaneous, mutual aid through organized nelghborliness, and as communitles grew and this help was not adequate, to the beginnings of organized charity as we know it today. By the $18^{\prime} 70^{\prime} \mathrm{s}$, public assistance through taxation took care of certain groups of people who could be cared for in institutions. All other ald was given by churches, benevolent societies, and individuals. Because of the chaotic state and overlapping of such private agencies, the Charity Organization Societies came into being. The purpose of these societies was to prevent duplication of relief, exposure of impostors and frauds, and the referral of "worthy" cases for help. The Louisville Charlty Organization Society was established in 1884, and was organized upon those principles. The Soclety frowned upon idleness and 
vagrancy, and established the Wayfarers' Lodge as a "work test" to determine if the unemployed were "worthy". In return for work, a night's lodging and meals for a day were given. Help in finding employment was given the "worthy".

When the Soclety was organlzed, no relief was to be given as it was felt there was sufficient rellef already being dispensed, and it should not be duplicated. It was felt that relief giving interfered with the function of the Society which was primarily that of service. Emphasis was placed on prevention. Investigation of all persons was made before referral to a benevolent society. It was soon found that frequently rellef was needed whlle the investigation was being made. Emergency relief became a part of the Soc1ety's expenditures.

The work of the organization was carried on by the Superintendent (later the General Secretary), the two agents (Iater Supervisors) in charge of the districts, and the "friendly visitors". The superintendent and the agents were the only pald members. The visitors performed their services without charge.

By the turn of the century, the need of paid, trained workers became apparent. All efforts to secure them or to organize the "Iriendly visitors" were unsuccessful.

From the earliest times, "charitable agencles 
have recelved casual gifts and have made sporadic efforts to collect additional funds." ${ }^{I}$ The income for the General Fund of the Charity Organization Soclety was dependent mainly upon voluntary subscriptions. Upon the payment of $\$ 5.00$, a person became a member. Publicity was through the newspapers and pamphlets distributed by the Society. Funds for relief consisted of voluntary gifts in cash, food, clothing, coal, and other goods given to the Society throughout the year and especially in times of stress.

$I_{\text {Warner, }}$ Queen and Harper, American Charities and Social Work, (New York: Thomas Y. Crowell Co., 1930), p. 537 . 
CHAPTER II

THE ASSOCIATED CHARITIES, 1908-1922 
CHAPTER II

THE ASSOCIATED CHARITIES, 1908-1922

The change in name of the Louisville Charity Organization Society to the Associated Charities symbolized a change in emphasis of work. Such an awareness had already taken place throughout the country, and the Louisville Society was keeping step with the other organizations. The Associated Charities tended to draw into close co-operation the many agencies already existIng for civic and social betterment. "To secure for the needy so far as can be done by the concentrated thought of the abler members of the soclety, is the object of the Associated Charities."I "More and more, social work was realizing and thoughtful community people understandIng that without co-operation the best and self-sacrificing labor was wasteful and to a large extent unfruitful." 2 "Soclal work in general had developed from ldeas of negative functions, such as investigation, registration and repression of fraud to a broadening and spiritualizing of aims of societies, co-operation, prevention and education. The principles remained the same but the emphasis

$I_{\text {Annual Report, }} 1907$.

2 Bernice Ellis, History of the Family Service Organization, (unpublished Master's thesis, University of Chicago, 1941), p. 56. 
had changed. "I

At the beginning of this perlod, most of the funds of the Louisville Soclety were used in investigation. This was true of most of the organized charity societies in the United States. The bellef had existed that there was plenty of relief dispensed, but that most of It was duplicated or went to fraudulent persons. While some relief might have been incorrectly administered, there were not sufficlent funds to care adequately for those in need. It was found that:

relief work was inadequately done; familles were broken up that could have been saved; more people died of tuberculosis and kindred diseases because they were poorly fed and housed. The effort of the Associated Char1ties at the present time is to preserve the family and the best influence of the home.?

The purpose of the Loulsville Society was: to bring together those who can and will give relief to their less fortunate neighbors and the unfortunate ones who cannot at all times care for themselves.... To ascertain genuine need and see that it is relieved, is the purpose of inyestigation and the treatment following 1t. 3

With the emphasis now placed on the treatment of the individual, the need for trained workers became more apparent and acute. In 1910, the Associated Char1-

${ }^{1}$ Amos G. Warner, American Charities, (New York: Thomas Y. Crowell Co., 1919), p. 473.

2 Annual Report, 1914.

3 Ib1a. 
ties secured its first trained executive, Miss Harriet Anderson, a graduate of the New York School of Philanthropy. From then on, the actual work was done by paid staff members rather than by volunteers. These paid staff members were not "trained" in the sense in which the word "trained" is defined today. The employment of an executive who was a graduate of a school of social work and paid staff members instead of volunteers was a step forward for the agency. The 1912 Annual Report lists three visitors regularly employed with the notation that others were secured as the demand arose. A large number of volunteers were st1Il used but the responsibility of the work rested upon the paid staff members. Beginning in 1905, stenographic help was also employed. Prior to that time, the "friendly visitors" wrote the records in long hand and did the clerical work themselves.

At the beginning of this period, the nature of the investigation of the individual changed to keep pace with the phllosophy of treatment. Investigation was st1ll considered necessary, not to expose or prevent fraud as in the earlier period but to learn the real nature of the difficulty of the individual so that an adjustment could be effected.

Family histories were secured, and comparisons of problems and treatments were made in order to help each Individual or family. Schools of social work de- 
veloped in order to study the scientific nature of the problem. Instead of considering material relief as incidental and impeding service, it was considered quite necessary in the treatment process. The Louisville Associated Charities not only recognized the necessity of emergency relief pending investigation but, in 1912, recognized that some families were in need of continued relief over a period of time during which treatment was given the famly. Two classifications of financial assistance were made: (1) "temporary relief" which included those cases which needed relief on a short time basis, and (2) "continued relief" which designated those clients who needed continued, regular relief. By that time, the agency had assumed the major relief responsibility in the city. The 1912 Annual Report stated that the expenditure for rellef for that year was more than double the previous year.

This means relief was more nearly adequate. Also it means that the other organizations in the city that do relief work in a small way are finding the possibilities of more extensive work and are caling upon the Associated Charities for help. 1

In connection with the increased service the Assoclated Charlties was giving, was the formation of the Legal Aid Committee in 1914.

The function of this committee is that of a peace maker and arbitrator and not that 
of a lawyer representing a client, irrespective of the merits of the case. The committee will, of course, represent a litigant in court when such services are necessary and proper. I

The Legal Aid Committee solicited the interest and cooperation of all those who knew of persons who needed legal service, or should be protected from some imposition or fraud. Its purpose malnly was that of protecting interests of the poor and those incapable of caring for themselves. In 1920, th1s legal ald work was taken over by the Jefferson County Bar with the organization of a Legal Ald Soclety. It was felt that an individual soclety for legal assistance would be of more value since during the preceding year only thirteen cases were reported. Two reasons for such a small number of cases were given: (I) the Legal Aid Committee was part of the Assoclated Charities, and people were reluctant to come to a charity organization for legal advice, and (2) the work of the Legal Aid Committee was not widely known. In continuing to consider other ways and means of giving service to families, in 1916, the Associated Charities helped finance the organization of a Social Service Exchange. Assistance was given until 1919 when the Exchange came completely under the financing and supervision of the Federation of Social Agencies. Due to the large number of applications from 
persons living in the western section of the city, a branch office was opened in that section, in 1916. The expense of the branch office was shared by the First . Christian Church and the District Nurse Association. To help meet the cyclical occurrences of unemployment such as Louisville and the whole country experienced during 1914 and 1915 and also to meet the seasonal fluctuations in employment affecting most industries, an Employment Bureau was opened in 1916. The work of that Bureau was considered constructive and should reduce the amount of necessary rellef. The Associated Charlties paid the salaries of two employees of the Employment Bureau. The clty provided rent, light, and heat in the City Hall. It was hoped that at some time the city would take over the entire expense and management of the Bureau. When the city failed to do so, and the Board of Trade could not, the project was dropped after 1918.

In attempts to save on the expenditures for relief, the Associated Charities made plans in 1919 to employ a visiting housekeeper or home economist. During that year, $\$ 10,000.00$ was spent for food alone. Although a home economist probably could not have substantially reduced that amount, it was belleved, the employment of the services of such a trained person would result in better food values being obtained. Accoraingly, a home economist was employed for the year of 1920 . The success of the Charity Organization Society 
in handing the tornado relief work in 1890 resulted in the Board of Trade calling upon the Associated Charities to handle the two flood disasters in 1913. Money ralsed by the Board of Trade through private subscriptions amounted to $\$ 7,203.69$. The C1ty Counc1l appropriated $\$ 6,200.00$, making a total of $\$ 13,403.69$. In January, 1913, four hundred ten families were cared for and eight hundred twenty-five families were provided for in March, 1913, by those funds. Of the total amount, approximately $\$ 10,000.00$ was spent for food, $\$ 1,300.00$ was expended for repairing homes, $\$ 700.00$ was spent for furniture and house rent, and the remainder was used for clothing and other relief.

Table 7 and Chart I show the proportion of relief to the total expenditure during that period. The total expenditures of money skyrocketed in comparison to expenditures during the previous period. Not only was that true, but also the money spent for rellef at times exceeded the money spent for all other services. There were several instances where the Ines inaicating such expenses crossed several times. That indicated that the agency attempted to adhere to its function of belng a service agency, yet was flexible enough in.times of stress or disaster to assume the role of the relief agency. The first time the relief expenditures exceeded other expenses was during the years 1914 and 1915, the depression years, but relief was still the outstanding 
TABLE 7

EXPENDITURES FOR RELIEF AND OTHER EXPENDITURES OF THE ASSOCIATED CHARITIES OF LOUISVILLE, KENTUCKY, BY AMOUNT AND PERCENT, 1909 THROUGH 1922

\begin{tabular}{|c|c|c|c|c|c|}
\hline \multirow{2}{*}{ Year } & \multirow[b]{2}{*}{ Total } & \multicolumn{2}{|c|}{ Relief } & \multicolumn{2}{|c|}{ Other } \\
\hline & & Amount & Percent & Amount & Percent \\
\hline 909 & $\$ 5,678.97$ & $\$ 1,501.51$ & 26.4 & $\$ 4,177.46$ & 73.6 \\
\hline 910 & $9,502.97$ & $2,753.34$ & 29.0 & $6,749.63$ & 71.0 \\
\hline $9 I I$ & $9,173.12$ & $2,596.45$ & 28.3 & $6,576.67$ & 71.7 \\
\hline 912 & $13,423.08$ & $5,552.28$ & 41.4 & $7,870.80$ & 58.6 \\
\hline 913 & $14,736.20$ & $6,607.19$ & 44.8 & $8,129.01$ & 55.2 \\
\hline 914 & $17,533.08$ & $10,640.74$ & 60.7 & $6,892,34$ & 39.3 \\
\hline 915 & $26,565.27$ & $17,458.68$ & 65.7 & $9,106.59$ & 34.3 \\
\hline 916 & $25,661.82$ & $17,4.58 .14$ & 68.0 & $8,203.68$ & 32.0 \\
\hline 917 & $28,672.83$ & $18,469.88$ & 64.4 & $10,202.95$ & 35.6 \\
\hline 918 & $43,713.50$ & $22,632.33$ & 51.8 & $21,081.17$ & 48.2 \\
\hline 919 & $34,569.87$ & $15,701.73$ & 45.4 & $18,868.14$ & 54.6 \\
\hline 1920 & $42,685.80$ & $22,764.88$ & 53.3 & $19,920.92$ & 46.7 \\
\hline 921 & $39,993.55$ & $16,368.69$ & 40.9 & $23,624.86$ & 59.1 \\
\hline 922 & $56,376.45$ & $20,505.00$ & 36.4 & $35,871,45$ & 63.6 \\
\hline
\end{tabular}




\section{CHART I}

EXPENDITURES FOR RELIEF AND OTHER EXPENDITURES OF THE ASSOCIATED CHARITIES OF LOUISVILLE BY AMOUNT 1909 THROUGH 1922

\section{Expenditures \\ in Thousands \\ of Dollars}

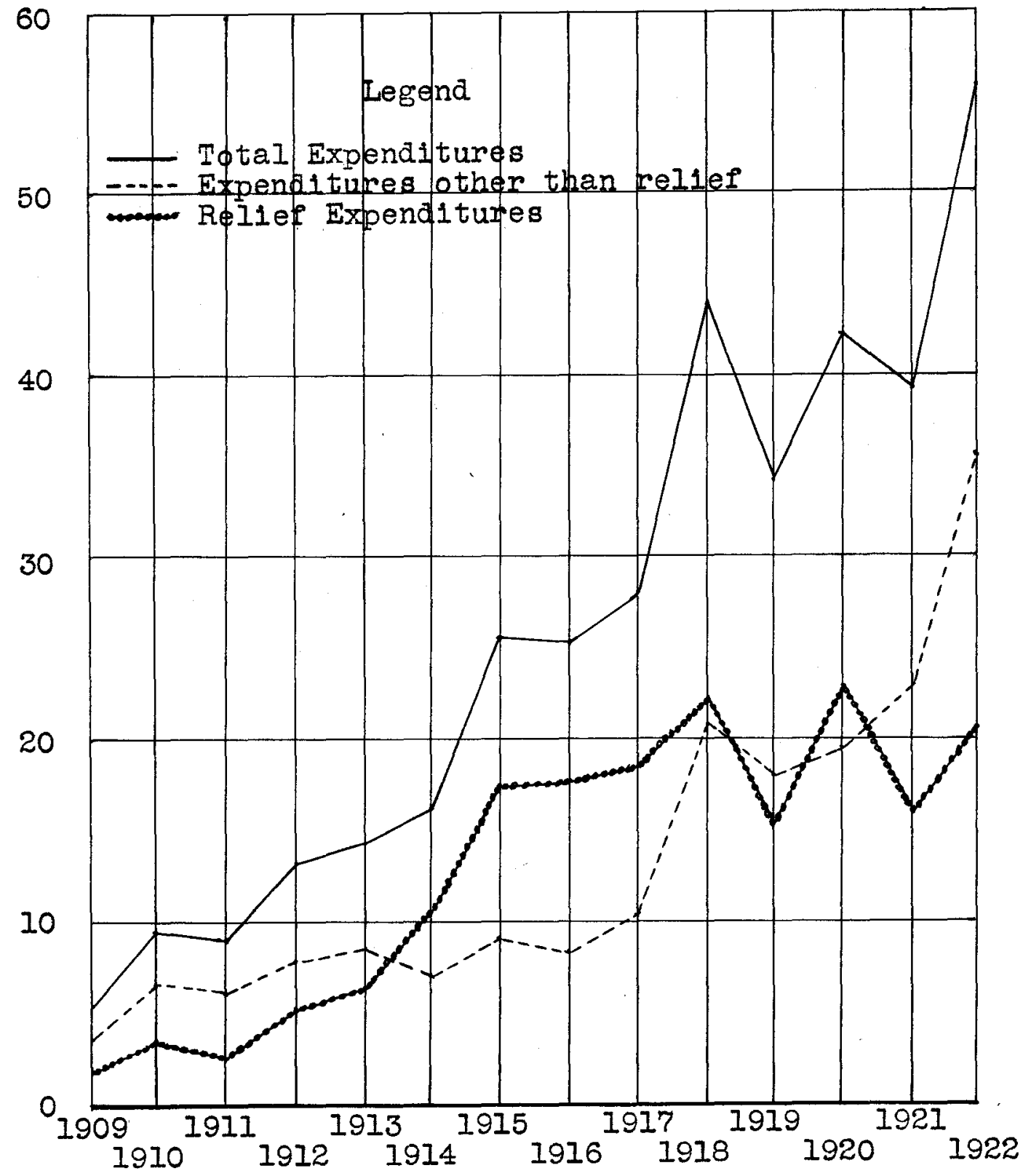


expense unt1l the end of the war in 1918, when service expenditures exceeded relief. This indicated that the agency was attempting to fulfill its function of service in rehabilitation of family life which was certainly most important following the war. "Due to unsettled conditions of the country during the past year, the Associated Charities has. intensified need for service, which will re-instate people to normal living." ${ }^{1}$

From the President's Report in 1920, we read:

When the Louisville Charity Organization Society was organized, the policy was principally to distribute properly material relief where most needed. Since then, the policy of all modern charity organizations has gone through a process of evaluation, so that at the present time it is considered much better to teach a family how to live properly and how to earn its own living.?

The Superintendent in his report in 1920 stated,

With the War well in the background, the year 1919 has been free from serious disaster. No flood, tornado, fire or epidemic has visited us, but there have been numerous conditions which tended to disrupt normal family life. Industrial unrest, street car strikes, coal strikes with increasing cost of food and clothing, higher rents, and scarcity of houses have made themselves felt. 3

Relief became paramount again in 1920, when the

1

Ib1a., 1918.

2 President's Report, Family Service Organization, January $13,1920$.

3 Superintendent's Report, Family Service Organization, January 13, 1920. 
51

depression following the war occurred. In 1921 and 1922, there was a sharp increase in the amount of other expenses while the relief expenditures remained relatively the same. That was a time the agency was again attempting to define its function and to present the idea forcibly to the public. A change in name, denominating the organization as being one of service instead of charity, was made.

As shown in Table 8, the proportion of money spent for salaries to the total expenditures during that period followed the trends indicated in Chart I (relief and total expenditures). The fact was emphasized that during the times the agency made special attempts to define its function as a service organization and attempted to get the idea over to the public, a greater proportion of money was then being spent for service or for salaries of workers to effect that service. It was noted that at the beginning of the period when the agency changed its name to Assoclated Charities to denote the fact that it was an organization of charities and again at the end of the period when the name was changed to Family Service Organization to emphasize the function of service, over half the money spent at both times was for salaries of the staff who dispensed service. In times of stress, however, the function of service, although not forgotten, was somewhat hidden by the need of meeting immediate reIlef needs. That the private agency was adaptable in 
TABLE 8

EXPENDITURES FOR SALARIES OF THE ASSOCIATED CHARITIES OF LOUISVILIE, KENTUCKY, BY AMOUNT AND PERCENT, 1909 THROUGH 1922

\begin{tabular}{lccc} 
Year & Total & \multicolumn{2}{c}{ Salaries } \\
\cline { 3 - 4 } 1909 & $\$ 5,678.97$ & $\$ 3,213.78$ & 56.6 \\
1910 & $9,502.97$ & $3,816.15$ & 40.2 \\
1911 & $9,173.12$ & $3,697.48$ & 40.3 \\
1912 & $13,423.08$ & $3,742.16$ & 27.1 \\
1913 & $14,736.20$ & $4,715.30$ & 32.0 \\
1914 & $17,533.08$ & $4,845.27$ & 27.6 \\
1915 & $26,565.27$ & $4,950.45$ & 18.6 \\
1916 & $25,661.82$ & $5,192.41$ & 20.2 \\
1917 & $28,672.83$ & $6,304.10$ & 21.9 \\
1918 & $43,713.50$ & $12,243.06$ & 28.0 \\
1919 & $34,569.87$ & $12,746.78$ & 36.9 \\
1920 & $42,685.80$ & $15,328.68$ & 35.9 \\
1921 & $39,993.55$ & $18,632.01$ & 46.6 \\
1922 & $56,376.45$ & $28,759.35$ & 51.0
\end{tabular}


meeting such needs was shown in 1915 when only 18.6 percent of the total expenaltures was for salaries. It appeared necessary at such times to sacrifice service to the more emergent needs.

Throughout the entire period, however, the need for service by trained personnel was not forgotten. Three workers were regularly employed in 1912, and nine workers were regularly employed in 1914. In 1919, seven workers with a superintendent and an assistant superintendent were maintained. In order to encourage further development of the workers, time-off was given them to attend classes at the University of Loulsville. In an attempt to maintain salaries in order to keep experienced workers, in the spring of 1919 one month's vacation with pay was given. In the fall of 1919, the agency pald one-half of the tuition for courses taken at the Univers1ty. Some leaves-of-absence with full pay for school attendance were given. In October, 1919, the regular vacation was changed to two weeks with pay and an add1tional two weeks were allowed for overtime during the year.

The funds of the Wayfarers' Lodge during the period of the Charity Organization Soclety were carried as a separate account. The Lodge was self-supporting. In the period, however, the expenditures began to exceed the income, and a deficit resulted. Despite the loss, 
the Associated Charities felt that the service which the Wayfarers' Lodge performed was valuable, and it was decided to carry the funds of the Lodge under the General Fund of the Agency. In that way, the expenses of the Lodge were borne partly by the sale of kindling wood and partly by contributions of which the General Fund mainly consisted. At times, the income of one year was approximately one-half to one-third of the expenses. In compiling figures, it was found that at the time the Wayfarers' Lodge went out of existence, the accrued defic1t exceeded $\$ 10,000,00$. The services of the Lodge were considered important in that it was the only agency in the city which offered facilities for the transient or homeless man. Also, by 1913, applications from men decreased, and attention was given to the needs of young applicants, sixteen to twenty years of age, with provision for more adequate planning for this group.

With the economic depression co-incident with the early years of the World War, applications for care at the Lodge increased. Although continuing its interest in the younger men and showing more disposition to try to work out plans for those applicants who showed an interest in long-time plans, both the Committee (Wayfarers' Lodge) and' the Board (of Directors) continued to be convinced of the wisdom of the "pay-bywork" lodging house. With the rapid increase in employment opportunities in 1917 and 1918, there was such a drop in applicants, the Board followed the recommendation of the Committee and clos ed the Lodge 
on April 1, 1918. During the following two years, the committee continued responsibility for the care of the bullding and consideration of applications for its rental. 1

After the discontinuance of the Wayfarers' Lodge, all homeless men were referred elther to the Hope Rescue Mission or the Salvation Army Industrial Hotel for Men. Table 9 shows that the amount of the total income and the proportion of income from various sources presented an entirely different picture from that of the preceding period of the Charity Organization Society. There was a marked and continued increase in the total amount of money received. The method of receiving funds abruptly changed during the period. Unt1l 1918, money was secured from the same sources; the bulk came from voluntary subscriptions. In 1918, a plan of federated financing was undertaken in the city, and thereafter the Associated Charities received most of its money from that source. Beginning in 1915, the "other" sources gradually increased in proportion to the total amount. "Other" sources included such items as rents, interest, refunds from persons benefitted, and miscellaneous, which up until that time were almost negligible. Refunds made up a large part of the "other" income, usually comprising

IMilared E. Bateman, Lay Participation in the Private Family Agency, (unpublished Master's thesis, University of Louisvilie, 1941), p. 78. 


\section{TABLE 9}

SOURCES OF INCOME OF THE ASSOCIATED CHARITIES OF LOUISVILLE, KENTUCKY, 1909 THROUGH 1922

$\begin{array}{rrrrrrr}\text { Year } & \text { Total } & \begin{array}{l}\text { Federation } \\ \text { of Social } \\ \text { Agencles }\end{array} & \begin{array}{l}\text { Contribu- } \\ \text { tions }\end{array} & \begin{array}{l}\text { Sale of } \\ \text { Kindling }\end{array} & \text { Others } \\ 1909 \$ 7,996.28 \$ & 0.00 & \$ 4,946.43 & \$ 2,449.85 & \$ \$ 1 \\ 1910 & 11,800.38 & 0.00 & 9,377.10 & 1,852.30 & 570.98 \\ 1911 & 11,404.52 & 0.00 & 9,937.32 & 1,467.20 & 0.00 \\ 1912 & 16,540.24 & 0.00 & 14,230.02 & 1,814.50 & 495.72 \\ 1913 & 16,292.76 & 0.00 & 14,105.04 & 1,422.18 & 765.54 \\ 1914 & 19,153.01 & 0.00 & 16,526.42 & 1,645.75 & 980.84 \\ 1915 & 32,616.25 & 0.00 & 28,551.85 & 1,955.90 & 2,108.50 \\ 1916 & 27,525.39 & 0.00 & 23,231.70 & 1,791.50 & 2,502.19 \\ 1917 & 28,573.43 & 0.00 & 24,390.49 & 1,212.75 & 2,970.19 \\ 1918 & 45,442.88 & 37,808.30 & 2,471.50 & 64.25 & 5,098.83 \\ 1919 & 37,012.75 & 32,762.22 & 265.50 & 0.00 & 3,985.03 \\ 1920 & 42,300.88 & 37,275.00 & 134.00 & 0.00 & 4,891.88 \\ 1921 & 40,819.29 & 33,938.70 & 194.75 & 0.00 & 6,685.84 \\ 1922 & 55,190.28 & 45,995.80 & 92.86 & 0.00 & 9,101.62\end{array}$


CHART II

SOURCES OF INCOME OF THE ASSOCIATED CHARITIES OF LOUISVILIE BY AMOUNT 1909 THROUGH 1922

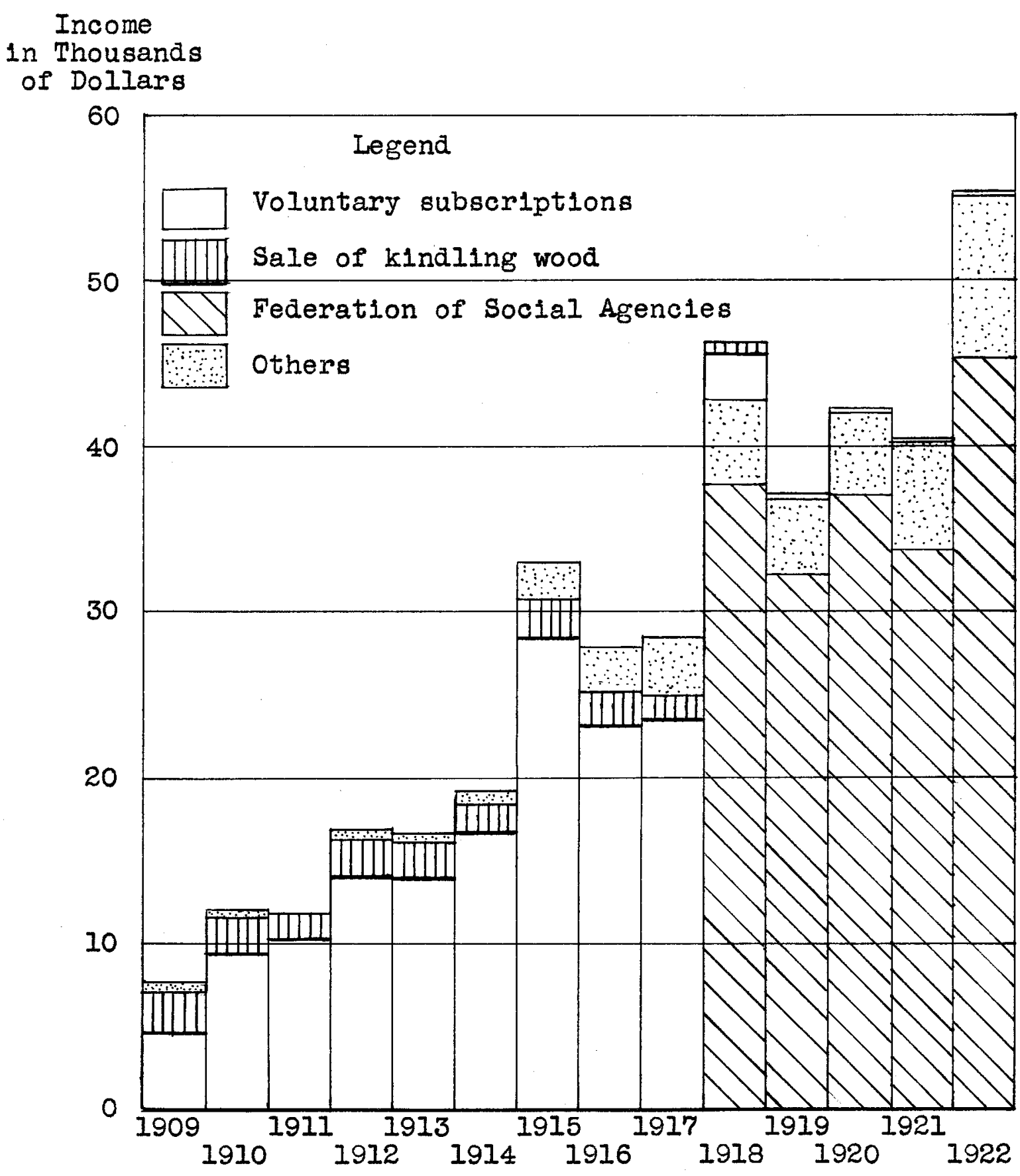


about half. After 1918, the amount of money recelved from rents increased. The amount of money from interest was small in proportion to the other two items. In that perlod, also, the agency began receiving bequests although they were quite small, and were included under voluntary contributions. A discussion of bequests and endowments will be taken up in a later chapter. ${ }^{1}$

During the early part of the period and when voluntary subscriptions provided most of the funds, the methods of raising money were similar to those of the Char1ty Organization Society period. After the advent of the federated financing, most of the publicity was taken over by the Federation of Social Agencles. Pamphlets were issued annually, and they included an explanation of the work of each of the member agencies. The newspaper continued to be the most influential medium of interpretation. Most of the publicity occurred prior to and during the campaign.

In 1918, the Assoclated Charities became part of the program of federated financing in the city. The 1dea was adopted in Louisville after it proved successful in a number of other cities. In Louisville, as in many other clties, it was found that a handful of wellto-do and a generous few supported the private agencles. Those people were solicited over and over again by many

Infra., p. 134. 
organizations of every description. There were many people who were able to give but were not contributing. Other people confined their donations to their "pet" charity. As a result of that situation, the idea of joint financing was earlier conceived, but the plan made no progress in this country until 1913.

As long ago as 1873 in Liverpool, England, a number of agencies induced to make their appeals through one offlce and on a common pledge sheet. A central committee circulated a list of socleties which it was sponsoring, and every subscriber put down the amount he was willing to give to each organization. 1

The first American experiment was in Denver in 1887 under the auspices of the Associated Charities. That was little more than a "charity chest". Difficulties arose out of attempts to make one agency serve the double purpose of direct service to clients, and the centralization of policy and finance for others. Those attempts had to be given up. The only other known experiments in joint financing before 1900 were the federation of Jewish Charities in Boston and Cincinnati. In both, the plan of organization was similar to that of the Denver plan except that it was restricted to Jewish agencies. One of the first cities to achieve success in federated financing was Cleveland. Being considered the

\section{IWarner, Queen and Harper, American Charities} and Soclal Work, (New York: Thomas Y. Crowell Co., 1930), p. 540 . 
first successful venture in that plan, some consideration will be given it. The following history is taken mainly from American Charities and Social Work by Warner, Queen and Harper. ${ }^{I}$ In 1900, the Chamber of Commerce in Cleveland created a committee on Benevolent Associations to carry on the work of charities endorsement. In addition to routine duties, a study was made of the whole of the city's giving in the years 1907 and 1909. It was found that six people were giving over forty percent of the total amount, and the number of contributors was decreasing. The committee advised adoption of some system of joint financing. After discussion and recommendations, the Cleveland Federation for Charity and Philanthropy (Including fifty-five agencies) was established in 1913.

Originally, the Chamber of Commerce intended to make the raising of money for philanthropic purposes a subsidiary function of its own, but the idea was abandoned in favor of a new plan. A trusteeship was organized of thirty persons, ten selected by the organizations to be inanced, ten selected by the givers, and ten by the Chamber of Comnerce. A full time executive who had experience in money raising was employed. A campaign was started, but it was not the "charity week" which later became so familiar. It was a program of letter writing, telephone canvassing, calls, and advertising carried on 
61

throughout the year. The individual agencies were encouraged to do their own soliciting.

At first, most of the money was raised by the separate agencies, but within four years, the amount raised through federation rose from thirty-two percent to seventy-one percent. The amount of money and the number of givers increased. There was no general budget. That and other sources of friction led to the formation of a Welfare Council in 1914, which was a council of social agencies. In 1917, the Federation and the Counc1l merged and was called the Welfare Federation of Cleveland.

Before that agency made any progress, the United States entered World War I. The Federation merged with the National Organization into the War Chest. After the Armistice, the War Chest Board became the Community Fund, and financed the Welfare Federation with its constituent agencies, and the Y. M. C. A. and the Jewish Federation, together with local quotas for State, national, and foreign organizations. The Community Fund really became a federation of federations.

After the war, the idea of joint financing spread rapldiy over the country. There were a variety of motives and a variety of plans.

Some Intended to protect givers egainst excessive and annoying solicitation. Some expected to increase the money-raising power of the agencles; some aimed at elimination of waste; others emphasized the integration 
and Improved quality of work along with

the centralization of financing. 1

In 1917, there were sixteen Community Chests in the whole country. In 1927, there were three hundred eight, and in 1937, there were four hunarea fifty-two. Today, there are over six hundred.

In Louisville, the movement for federated financing began in 1915. In December, 1915, the plan as practiced in Cleveland was discussed by the Board of Directors of the Associated Charities. Questionaires were sent to various agencies in the city regaraing such a plan, and the replies received appeared favorable. In March, 1917, Mr. Allen of the Finance Committee of the Associated Charities was appointed Chairman of a Board of Trade Committee, which officially approved the plan and brought about the actual organization of a Federation in November, 1917, called the Louisville Federation of Social Agencies.

While the Federation was organized for the economic collection and distribution of funds by one unified appeal, replacing the separate and often wasteful and expensive collection methods of separate campaigns, the founders were even more interested in studying the city's welfare needs and trying to meet them through good social planning. 2

The purpose was "to serve Louisville by advancing the

\section{1}

Ib1d., p. 542 .

2 Paper "1917-1940 - Twenty-three Years of Service" by Mary B. Stotsenburg, Executive Secretary, Community Chest of Louisville and Jefferson County. 
financial, educational, and social effectiveness of the co-operating organizations." 1

The objects of the corporation were:

(a) To simplify the raising of funds by providing a single agency through which, solicitation and collection may be made for all organizations which now are or hereafter may become members of the corporation and thus to save the time of those solicited and those soliciting.

(b) To endeavor to eliminate all plans of money raising under which a large part of the amount contributed by the public is absorbed in expense and commission and of which a small part only reached the organlzation treasury.

(c) To standardize the accounting and work of member organizations.

(d) To prevent duplication of activities. - (e) To bring about a better mutual understanaing among member organizations, to foster a spirit of co-operation and mutual helpfulness, and by creating a wider interest through greater publicity, to provide increased funds by means of which each organization may be enabled to do more adequate work.?

The name of the Louisville Federation of Social Agencies was changed to the Welfare League in January, 1919, because the original name was too long and cumbersome.

The first money raised by the Federation was for the year 1918. In 1917, there were 3,400 contributors who gave a total of $\$ 138,003.00$ to the twenty-

$I_{\text {Pamphlet by Louisville Federation of Social }}$ Agencies, 1920. On f1le at Family Service Organization. 2 Ibia. 
five agencies which later composed the Federation. Table 10 shows both the increase in number of contributors and the amounts contributed after the inauguration of federated financing.

\section{TABLE 10}

NUMBER OF CONTRIBUTORS AND AMOUNT OF CONTRIBUTIONS UNDER FEDERATED FINANCING

Year

1917

1918

1919

1920

1921

1922
Number of Contributors

3,400

5,450

11,851

15,000

21,000

33,858
Amount of money

Subscribed

$\$ 138,003$

180,000

247,635

266,612

339,000

338,282

A great deal of publicity by the press was given the movement of federated financing in the city.

Uniform figures for all agencies were a prerequisite for joint financing. Nothing gave more impetus to the budgeting of income and expenses of the individual agencies than the Community Chest movement. As mentioned in the preceding chapter on the Charity Organization Society, bookkeeping frequently was careless and inaccurate. 1 There were no comparable figures between the agencles, and most of the funds were

${ }^{I_{\text {Supra. }}, p .} 30$. 
"raised and expended on a basis of guess and hope."I The Associated Charities Society of Louisville was a pioneer in keeping accurate books, and during the years immediately preceding the adoption of joint financing in Louisvilie, that agency was attempting to procure other agencies in the city to work towards uniformity in financing, budgeting, and accuracy in keeping records of their financial transactions. In September, 1913, the Board of Directors of the Associated Charities decided to have the books audited by a pubI1c accountant. Accordingly, in the year of 1914, the firm of Meldrum and Meldrum, public accountants and auditors, were instructed to design and install a comprehensive accounting system for the association, revising the system theretofore in use. The new system was inaugurated on May 1, 1914. Prior to that time, the accounting was all handled on a "recelpt and disbursement" basis which falled to present an accurate status of the accounts involved. The new system was designed on a "revenue and expense" basis, which attained an actual and accurate record of the varlous accounts. The first audit of the books of the Associated Charities was made for the period of October 1 , 1913 to September 30, 1914. Certain discrepancies

I Warner, Queen and Harper, American Charities and Social Work, (New York: Thomas Y. Crowell Co., 1930), p. 537 . 
were rectified at that time, and since then, this system of bookkeeping together with annual audits have prevented inaccuracles.

The change in bookkeeping agreed with the philosophy of the agency in the period - a philosophy toward social work as a profession with trained personnel and service to individuals. With the advent of the Federation of Social Agencies, the name of Associated Charities became a misnomer, resulting in the changing of its name to Family Service Organtzation in 1921. The new name more aptly described the agency's function of service rather than charity. In summary, the period of the Associated Charities (from 1907 through 1922) was one of co-operation between the various agencles. There was a tendency to draw into closer co-operation the already existing charitable agencies which before had shown a great deal of competition among themselves. It was a period of cooperation rather than competition. Social work had turned from the negative to the positive. Emphasis was placed on the treatment of the individual, and with this began the development of the 1dea of social work as a profession. Trained social workers were needed, and they began replacing the volunteer worker of the preceding period. Rellef was considered as part of the treatment of the individual and a means to an end 
rather than an end in itself. With the recognition of the necessity of both emergency and continued relief, the agency increasingly assumed more of the responsibility of the relief needs until finaliy it shouldered the major rellef load of the city.

Commlttees designed to aid in the service and treatment of families were formed. They included the Legal Ald Committee and the Employment Bureau. The formation of a Soclal Service Exchange and the employment of a home economist were other evidences of service to the citizens of the city.

The period included the depression years of 1914 and 1915, the war period of 1917 and 1918, and the post-war depression of 1920 and 1921. The private agency possessed the flexibility to meet the pressing needs which accompanied those crises. The stress of the times necessitated a curtailment of the services to meet the more emergent needs. As times improved, the services of the agency increased. Throughout the entire period, the agency attempted to define its purpose and function as one of service to the public.

An outstanding innovation of the period was the change in the method of ralsing money; i.e., the plan of joint financing, which evidenced increased co-operation between agencles. The federation plan of financing in which a number of agencies combine and utilize one 
campaign to secure funds for all the agencles was adopted. The Associated Charities was instrumental in inaugurating the plan in Louisville. The Louisville Federation of Social Agencies was organized in 1917, and subsequently, for purposes of simplification, was renamed the Welfare League.

The Associated Charities, in 1913, inaugurated a system to increase the accuracy of its bookkeeping, budgeting, and financing, including annual audits of 1ts records. The system was a vast improvement over the haphazard and unsystematic methods theretofore used. The recognition of the agency as one of service resulted in changing its name, in 1921, to the Family Service Organization. 
CHAPTER III

THE FAMILY SERVICE ORGANIZATION, 1923-1928 
THE FAMILY SERVICE ORGANIZATION, 1923-1928

The agency under the name of the Family Service Organization started its work of service with emphasis on prevention. There was greater emphasis than ever before on the need for education in scientific methods of dealing with the difficult problem of human relationship. The body of knowledge for training was constantly increased by research and the infiltration of new knowledge from other fields. Correlated with that was an increased conviction of the possibility through case work of assisting in the adjustment of human relationships. This conviction was expressed in a statement by PhIlip Klein, Executive Secretary of the American Association of Social Workers:

The social workers have discovered a new method, applicable in large numbers and much more efficacious than that of handing out material relief, namely, case work or personal adjustment. This method has been found excellent, not only in supplementing material rellef, but also in many cases, supplanting it. The case work technique has been the greatest discovery in the tool chest of the soclal worker concerned with the group that is submerged because of social and industrial conditions, and because, frequently, of biological conditions... Caseworkers, therefore, see a large and attractive field of plying this newly discovered tool, namely, the case work method, in an extensive fleld concerned with the personal relations of individuals wherever 
71

found in the social scheme. 1

The refinement of the case work method brought with it conviction of the need for more adequate relief in contrast to the subsistence standara of the past, and more awareness of the effects of relief on the recipient. The possibilities of casework also brought a concern over high case loads and attention to definition of function In contrast to the eagerness to take services in the earlier periods. Where both private and public agencies existed in a community, there were beginning efforts to define division of responsibility. The private organization generally took responsibility for developing new resources for groups; although the family agencies believed such groups should no longer be their responsibility. 2

The Loulsville agency was progressing in these ideas along with the rest of the country. The agency's function was re-defined to stress the family as an entity. "Family work was basic in the trend toward reducIng and preventing poverty and disease and preventing

${ }^{1}$ Letter from Philip Klein to David C. Liggett, Director of the Community Chest, December 17, 1924. On file at the Family Service Organization.

$2_{\text {Milared E. Bateman, Lay Participation in the }}$ Private Family Agency, Loulsville, Ky., (unpublished Master's thesis, University of Louisvilie, 1941), p. 102 . 
family break-down." I Although the emphasis was on service, the agency increasingly recelved the "overflow" of other agencies. In 1923, Mr. Linton B. Swift, General Secretary of the Family Service Organization, brought attention to the lack of facilities in the clty for dependent drug addicts, chronic invalids, and the aged and infirm. The lack of such facilities necessitated the Family Service Organization caring for those groups as well as it could. Attention was also called to the lack of State allowances for dependent widows and deserted mothers.

In September, 1923, the Central Council proposed a resolution authorizing and directing the staff of the Family Service Organization to refuse to accept responsibility for any dependent chronic invalid, convalescent, or drug addict, where, in the opinion of a reputable physician, such applicant was an institutional case. No action was taken on this resolution, but it was significant in that, for the first time in Louisville, consideration was given to closing intake to the families of such persons. Such families, in other cities, were cared for by public assistance programs.

Throughout the remainder of the 1920 's, the problem in Louisville for caring adequately for the fami-

${ }^{1}$ Marian E. Prinz, A Study of the Family Service Organization, Loulsville $\mathrm{Ky}$. in Reference to Intake. 1884-1940, (unpublished Master's thesis, University of LouIsviIIe, 194I), p. 64 . 
lies under the agency's care became increasingly acute. The agency required special training for its workers and attempted to maintain a high degree of service; however, the "overflow" from other agencies caused a constant pressure on the Family Service Organization, both in the quality of work and the amount of relief needed. The agency was criticized for the inadequate relief given to Its famliles, an inadequacy which resulted from its attempts to care for too many families with its limited funds and staff. Such limitations made impossible the doing of a thorough job.

Each year the agency faced a financial crisis because of insufficient funds. Many familles under its care were public responsibilities. There were constant discussions as to how to secure more funds, how to decrease the number of families, and how to maintain the standard of service to families. It was truly a situation in which only the then present needs could be met with no future planning. Every possible resource was tapped incluaing relatives, friends, and churches. In spite of that, relief was inadequate, and the inadequacy resulted in much suffering.

Table II and Chart III show the total expend1tures, and the amounts and percentages spent on relief and all other expenses during the period. A decided contrast is revealed by comparing the expenditures for the period as shown in Table 11 with those for the pre- 
ceding period as shown in Table 7. In 1928, twentysix times as much money was spent for rellef as was so

TABIE 11

EXPENDITURES FOR RELIEF AND OTHER EXPENDITURES OF THE FAMILY SERVICE ORGANIZATION OF LOUISVILLE, KENTUCKY, BY AMOUNT AND PERCENT, 1923 THROUGH 1928

Year Total Ex- $\begin{gathered}\text { Relief Expendi- } \\ \text { penditures }\end{gathered} \frac{\begin{array}{c}\text { Other Expendi- } \\ \text { Amount Percent }\end{array}}{\text { Amount Percent }}$

$\begin{array}{rrrrrr}1923 & \$ 85,572.90 & \$ 36,167.23 & 42.3 & \$ 49,405.67 & 57.7 \\ 1924 & 100,648.53 & 42,524.35 & 42.3 & 58,124.18 & 57.7 \\ 1925 & 126,561.10 & 61,190.20 & 48.3 & 65,370.90 & 51.7 \\ 1926 & 124,648.46 & 53,795.08 & 43.2 & 70,853.38 & 56.8 \\ 1927 & 139,937.12 & 64,200.33 & 45.9 & 75,736.79 & 54.1 \\ 1928 & 145,044.77 & 67,651.02 & 46.6 & 77,393.75 & 53.4\end{array}$

spent in 1909, and three times as much as was so spent in 1918. In spite of the large amount of money spent in 1928 , the average per family was small, about $\$ 10.00$ per family per month. The proportion of money spent for relief was fairly consistent during the period, and was slightly less than half of the total amount of money spent. According to Chart III, total expenses, rellef expenses, and other expenses increased continuously during the period except for the year of 1926, when relief expenses and total expenses decreased from the preceding year while other expenses increased during that year. With the Family Service Organization, as before 
EXPENDITURES FOR RELIEF AND OTHER EXPENDITURES OF THE FAMILY SERVICE ORGANIZATION OF LOUISVILLE, KENTUCKY, BY AMOUNT 1923 THROUGH 1928

Expenaitures

in Thousands

of Dollars

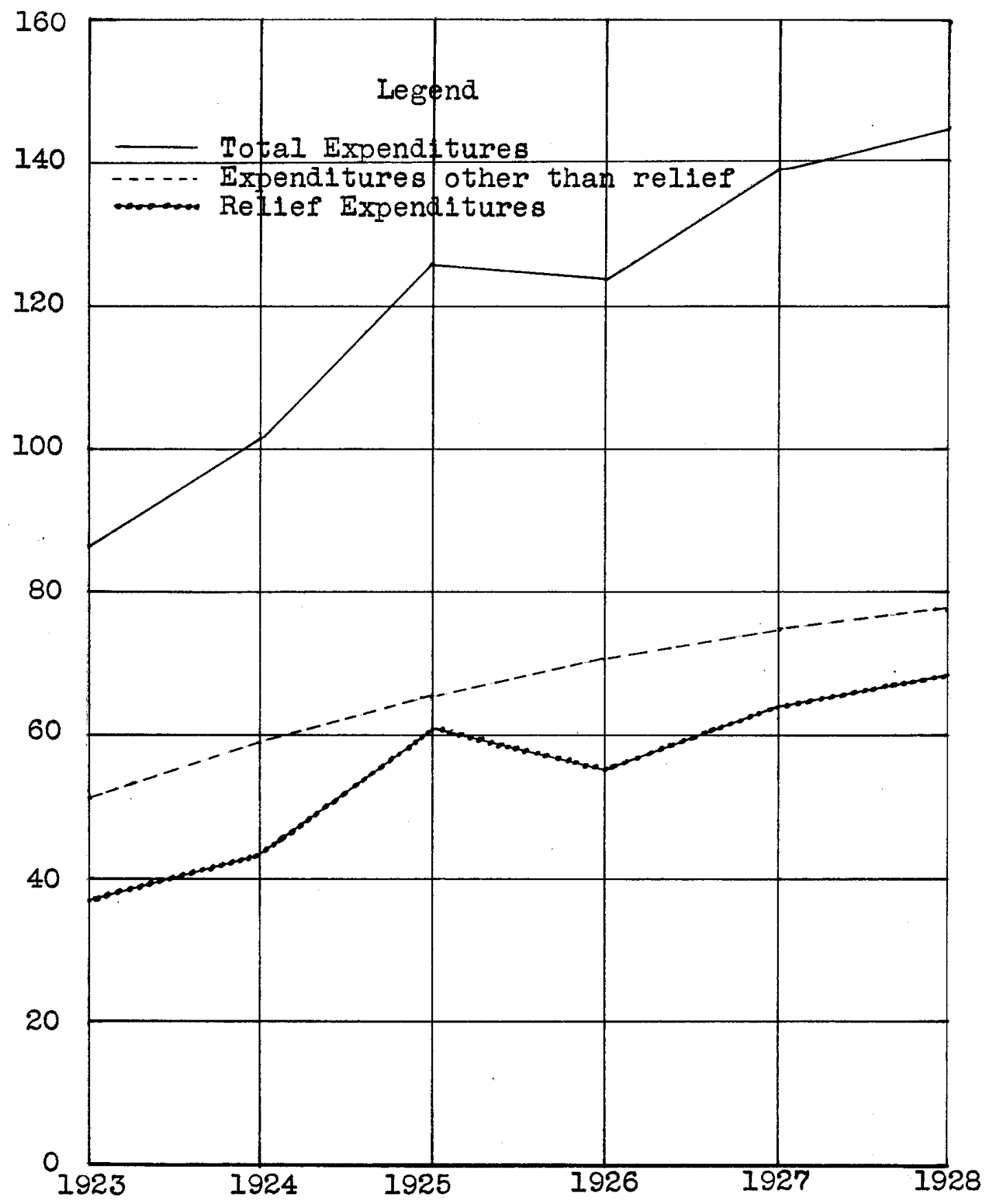


stated, receiving the "overflow" from other agencies, greater emphasis was placed on the need for more public participation, especially in the field of the aged people, the chronically 1II, the unemployed, the dependent widows, the feeble-minded, and the epileptic.

TABIE 12

\section{MOTHERS' AID AND OTHER PUBLIC RELIEF IN TWELVE CITIES OF THE UNITED STATES}

$\quad$ City
Akron
Columbus
Denver
Indianapolis
Kansas City
Minneapolis
Philadelphia
Providence
Rochester
St Paul
Toledo
Louisvilie

Akron

Columbur

Indianapolis

Kansas City

Minneapolis

Providence

Rochester

Toledo

Louisville

$$
\begin{array}{r}
\text { Total } \\
\\
\$ 90,000 \\
115,000 \\
95,000 \\
90,000 \\
27,000 \\
196,656 \\
421,500 \\
26,500 \\
188,058 \\
220,500 \\
92,100 \\
3,000
\end{array}
$$

Other Public
Relief

Aia

\$30,000

25,000

95,000

75,000

27,000

78,000

118,656

414,000

7,500

26,500

115,948

65,500

25,000

3,000

Table 12 from "History of the Family Service Organization" shows the amount of public rellef given in a number of other cities in the United States during 1925.

A Mothers' Aid Bill was passed by the Kentucky

Legislature in 1927, but there was no State-wide program.

$I_{\text {Bernice Ellis, History of the Family Service }}$

Organization, (unpublished Master's thesis, University of Chicago, 1941), p. 104. 
A plan of Mothers' Aid was operated in Jefferson County through the Home Placing Division of the Louisville and Jefferson County Chilaren's Home beginning in 1928. The department was not able to care fully for all the famiIles that were its responsibility.

TABIE 13

\section{SAIARY EXPENDITURES OF THE FAMILY SERVICE ORGANIZATION OF LOUISVILIE, KENTUCKY, BY AMOUNT AND PERCENT, 1923 THROUGH 1928}

Year

1923

1924

1925

1926

1927

1928
Total

Expense

\$ $85,572.90$

$100,648.53$

$126,561.10$

$124,648.46$

$139,937.12$

$145,044.7 ?$

$\frac{\text { Salaries }}{\text { Amount }}$

$\$ 39,352.23$

$47,336.34$

$52,335.03$

$56,070.93$

$60,401.07$

$62,278.93$
45.9

47.0

41.4

45.0

43.2

42.9

Table 13 shows the proportion of money spent for salaries to the total amount of money spent. The period was one of great turn-over among the staff of the agency. More and more emphasis was placed on training. The Louisville School of Social Work was organized in 1922, and the workers in the agency enrolled in the School. Some of the workers whose salaries were small were assisted with their tultion by the agency. In 1926, the School of Soclal Work ceased operation, which necessitated the agency's development of its own training program. 
The workers were encouraged to secure formal education at the universities and schools of social work. When the facilities of such institutions were not avallable, groups of the workers were taught by the Executive Secretary. The agency maintained such "in-service" training program. There was also inaugurated the plan of apprentice training in which a worker volunteerea her services for a certain length of time before she became a pald member of the staff. The phrase "trained worker" assumed a more specific meaning. A "trained worker" was one with some formal education in the fleld of social work.

The proportion of salaries to total expenses remained fairly consistent during the period; slightly less than half of the total expenditures was spent for salaries.

\section{TABLE 14}

SOURCES OF INCOME OF THE FAMILY SERVICE ORGANIZATION OF LOUISVILLE, KENTUCKY, I923 THROUGH 1928

$\begin{array}{lrrr}\text { Year } & \text { Total Income } & \text { Welfare League } & \text { Other Income } \\ 1923 & \$ 80,350.69 & \$ 71,844.58 & \$ 8,506.11 \\ 1924 & 94,110.73 & 88,327.00 & 5,783.73 \\ 1925 & 118,967.72 & 114,798.92 & 4,168.80 \\ 1926 & 122,565.27 & 117,607.70 & 4,957.57 \\ 1927 & 134,123.67 & 129,423.68 & 4,699.99 \\ 1928 & 140,207.58 & 136,639.11 & 3,568.47\end{array}$




\section{CHART IV}

SOURCES OF INCONE OF THE FAMILY SERVICE

ORGANIZATION OF LOUISVILLE, KENTUCKY,

Income

1923 THROUGH 1928

in Thousands

of Dollars

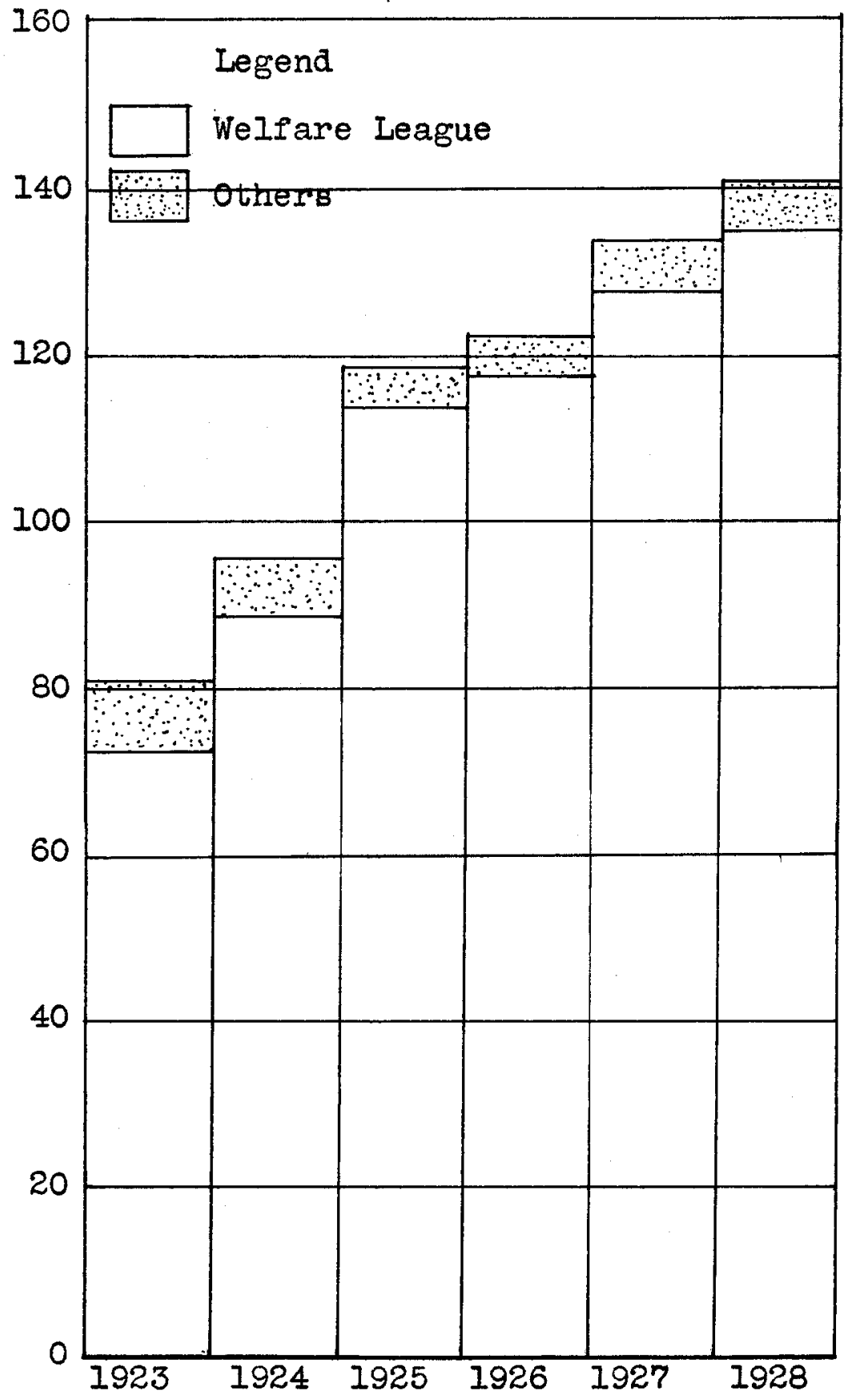


80

Table 14 and Chart IV show the amount and source of income which the agency received. Practically all the money came from the Welfare League, which tended to prove that the plan of joint financing was successful. Only a very small proportion came from other sources, those being mainly in the form of interest and refunds. Toward the end of the period, the money received from discounts on merchandise purchased reached a sizable sum. Other income consisted of money received from interest on the organization's endowment funds, refunds from individuals helped, discounts on purchases, and contributions made directly to the agency for specific purposes or specific families. The amount of income steadily increased but the amount was still not enough to adequately meet the needs of the clients.

In 1924, the Welfare League was re-organized into the Community Chest after study of the development in other cities. The Community Chest took over all the assets of the Welfare League, and while there was a change in organization, there was no change in objectives. Under the Welfare League, the Board of Presidents was made up of the presidents of the member agencies and the Board of Workers consisted of the executive secretaries of the agencies. In the organization of the Community Chest, each agency was a member and had two representatives. The representatives of the agencies were members of the 
81

Central Council, which was the governing body, and elected its own officers. The President appointed an Executive Committee to assist in the management of the Community Chest.

A great step in progress was made in the organization of the Health Council and the Council of Soclal Agencies of the Community Chest. The functions of finance and social planning are dual aspects of the same basic function. The Councils included as members non-Chest as well as Chest agencies, and tax-supported as well as privately-supported agencies. Through the Counc11, all these agencies come together for the joint consiaeration of common problems, for the introduction of better work standards, and for the planning and formation of new social enterprises, for united action on matters of common interest and for the development of general co-operation in the community. 1

The Community Chest proved that the federated plan of financing saved many times the duplicated cost of separate appeals and separate collections. Cost figures of agencies in 1917 were not avallable, but an estimate of the cost of raising money by the individual organizations varied from fifteen percent to sometimes as high as forty percent. The Community Chest also saved the time of volunteer solicitors, the time of the Board members, and the staff of the agency. The entire cost of operating the Community Chest in 1939 was seven percent of the amount subscribed. This was made up of administrative and collection expense of 3.7 percent and

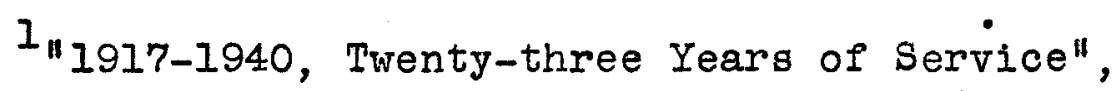
mimeographed paper on file at the Community Chest. 
campaign expenses of 3.3 percent.

One of the important achievements of the Community Chest was the establishment of a budget control for the member agencies. A Budget Committee studied the annual requests of the agencles together with the needs of the community, service reports of the agencies, and detalied service and cost figures which were prepared by the Community Chest office. The Budget Committee recommended a campaign goal to the Central Council. After the campaign, final allotments were made to the agencies on the basis of the amount of money secured. Each agency filed a monthly requisition showing actual and estimated recelpts and disbursements. A Finance Committee of the Central Council of the Community Chest supervised the distribution of funds and passed upon the monthly expenditures.

The actual organization and procedure of Community Chests varled greatly from c1ty to city; however, there were a number of principles of general acceptance.

(I) One of these is buagetary control, which means that each agency prepares in advance a detailed budget, which when approved by the Chest or Federation, is not to be exceeded without permission of the controlling body.

(2) The whiriwind campaign has been quite generally adopted as the principal, if not the only, means of raising money.

(3) In many cities, "the immunity rule" has been adopted. This means that persons who contribute to the Community Chest are promised freedom from further solicitation during the year by agencies within the Federation. 
(4) A less general policy is that of providing for designated gifts. Many givers object to certain organizations, while others are anxious to throw their whole support behind agencies in which they are especially interested. Opportunity is frequently given for the contributor to specify how he wishes his donation to be given. Other fiscal policles which seem to be gaining rapialy are:

(5) centralized accounting, and

(6) centralized purchasing.

Among the non-financial principles that have won highest acceptance are:

(7) centrallzed, continuous, educational publicity, and

(8) the co-ordination of social programs.

These last two have been taken over by the Counclis of Social Agencies rather than developed by the Community Chest. 1

"Whirlwind campaign" usually meant that solic1tors spent a week or ten days in raising funds. There was much publicity at that time, "pep" meetings were held, and the campaign finished with a "wind-up" dinner. Large givers were solicited ahead of time and their contributions were specified as "special gifts". The solicitors were divided into divisions anā teams, and there was a great deal of rivalry between them. Exceptions to the "imnunity rule" were for special campaigns for bullding funds, disasters, and other unforseen emergencles.

The Louisville Cormunity Chest adhered generally to the organization and procedure listed above, with the exception of the centralized accounting and centralized

$I_{\text {Warner, Queen \& Harper, American Charities and }}$ Social Work, (New York: Thomas Y. Crowell Co., 1930), pp. 543-545. 
purchasing.

Experience showed that Community Chests increased the amount of contributions and the number of givers. The gain's were most marked in the early years of the federation and leveled off after a time. The cost of raising funds decreased. Convenience to the contributors increased, and co-operation among social agencies increased.

The ultimate test of a welfare federation is not in the amount of money which it collects nor in the number of its contributors, nor in the degree of immunity which it may give from annoying drives; but in the number of well-informed and well-disposed citizens whom it discovers and associates for the purpose of doing what they can to secure a good life for themselves and their nelghbors. 1

Along with the success of the Community Chests, there came certain dangers or arguments against them. The most important and difficult problem was that of control. The Chest was concerned primarily with business and publicity problems rather than social problems, and the tendency was to impose a certain control which decreased the freedom and initative of the participating agencies. Before joint financing, each agency had its own "say so". When some one else financed, independence was apt to disappear.

\section{1}

Edward T. Devine, WeIfare Federations, p. 53, cited by Warner, Queen and Harper, American Charities and Social Work, (New York: Thomas Y. Crowell Co., 1930), p. 546 . 
The Chest was unable to interpret effectively the work of all the agencies represented. There was money-raising publiclty which was not the type which interpreted the underlying spirit of the individual organizations. There was a tendency to level standards downward. The Chest subsiaized weak agencies at the expense of the strong ones. There was the problem of what agencies would be included. Generally, groups were omitted on the grounds that the Chest was Iimited to agencies acceptable to the majority of the population. The Chest was conservative and was hesitant to a1d "radical" movements. The problem arose as to what provision was to be made for capital for buildings and equipment; usually, that was left to the individual agency to make its own arrangements.

If the Chest did not attain its financial goal, It was difficult to know the decision to make. Sometimes the deficit was carried by the Chest; sometimes the budgets of all agencles were cut proportionately. The above mentioned dangers were important in pointing out tendencies to be guarded against. They did not represent weaknesses which were inherent in the federated plan of raising money. For the most part, the Community Chest could and did protect itself against them.

In joint financing, one objection was inherent in that the contributor was far removed from his gift. When an individual contributed to an agency, he became 
identified with it, and his interest followed his gift.

A real danger lies in the fact that success in raising funds depends on high powered, spell-binding methods and intensive soliciting effort rather than the building of an individual and deeply personal interest in social work itself. The Chest organization must hold and increase the special interest of the contributor in the work being financed, and must aid the agencies participating in the Chest to utilize that interest in other forms of work. 1

During the period, with increased awareness of the importance of budgeting and bookkeeping, and the "budget control" of the Community Chest, greater emphasis than ever before was placed by the Family Service Organization on the budget and its presentation. A factor, no doubt, of the value of the detail presented was due to the great need of more adequate funds and the importance of acquainting the Budget Committee of the Community Chest with such need. The 1925 budget prepared and presented by the Family Service Organization was the first one of such detail. That budget included a "Table of Contents" and an index to the various sections; a foreword explained that the budget was to be considered in two divisions: (A) the amount spent for all forms of work of the agency, which were the various services given, and (B) the amount given in material relief alone; that allowance was to be made for service, the "working budget", which determined the quality and amount of work which the agency could do and which offered the best basis for comparison with

$1_{\text {Proctor \& Schuck, Flnancing of Social Work, }}$ (Chicago \& New York: A. W. Shaw Co., 1926), p. 100. 
other agencies which ald not give relief; that it was understood that the Budget Committee of the Chest was busy and the members willingly gave of their time; that It was regrettable that it was necessary for the Committee to have to decide in two hours the quality and extent of the work of the Family Service Organization for a whole year and the welfare of 2,400 families under its care.

The first section of the Budget dealt with "The Burden Carried", and in this, an explanation was made that the Family Service Organization was the only nonsectarian agency for family rehabilitation and relief, and carried a load which in other cities was borne by several agencies, as (I) The public or city relief departments, (2) Mothers' Aid, (3) Bureaus of Catholic Charities, and (4) Institutions for the Physically Handicapped.

The next section explained that an adequate budget was not asked since it was impossible to estimate the total spent in any city for the above purposes; that It was possible, however, to secure amounts spent by the two principal relief-giving agencies; 1.e., the Famlly Society and the City Relief Department. Reference was made at this point to such figures received from eight cities. The section continued with the statement that the agency recognized the need for economy at that time and did not expect to make any increase financially in 
view of conditions; that it was hoped that the agency would not be pushed backwards; that the only request was that restoration would be made to the budget of the things which were sacrificed in 1924 in order to save $\$ 10,000.00$ from the approved service and operation budget to be applied on rellef in 1924.

There followed an explanation of increases and decreases in the budget. The increases in the 1925 budget over that for 1924 were shown in two ways: (1) by comparison with the budget granted the agency in 1924, and (2) with the actual expenditures in 1924 which reflected a crippling of the staff and the work after budget reductions, in order to avoid asking the Chest for an additional $\$ 11,000.00$ for materlal relief. A comparison of the 1925 estimate with the 1924 actual expenditures showed that in order to provide the necessary fund for relief, the emergency saving of $\$ 10,000.00$ made from the Service and Operating Allowance serlously crippled the staff and the work.

Many necessities were sacrificed, workers were allowed to take leaves of absence, three workers went to a sanatorium, one without salary, two with part pay. This was the only agency where the workers pald their own expenses to the National Conference; publicity and other work was paid by specific contributions from members of the staff. Each worker cared for an average of seventy-five families per month. It was necessary for some famllies to go without attention.1 
The proposed budget continued with an analysis of the major increases of the 1925 estimate over the 1924 actual expenditures. Such Increases included a new autornobile, a safe, a district office, slight salary increases, some of which increases had been authorized for 1924 but not utilized. Under material relief, the buaget proposal stated that consideration of the necessity for adequate relief and its intimate connection with other forms of service should not be neglected; that services performed and relief given were considered inseparable; that allowance given a widowed mother to enable her to keep her chilaren in school was more than a gift of food to keep the family from starving and was distinctly a service designed to make the chilaren better future citizens; that services which teach a family how to manage Its own resources so as to remain inaependent, was a better form of relief from financial distress than thoughtless and continuous gifts of food or money alone; that the material relief given was greater than a few years prior, but still utterly inadequate, and was given only where vitally needed; that to reduce the standard of relief further would be disastrous; that all agreed that the preventive, educational, and constructive work which the Family Service Organization and other agencies were doing was of greater ultimate value, but the then present suffering could not be neglected in order to look to the future; that if the suffering were neglected, the 
public would rebel and all the Community Chest agencies would suffer; and that the signs pointed to a slow recovery from the then industrial depression.

In conclusion, the budget statement pointed out that the Family Service Organization was not endeavoring that year to secure resources which would enable it to do a complete and adequate job; that such was a slow process and the Chest was as desirous as the agency of reaching such an ideal; and that, in the meantime, the financlal Iimitations of the Chest were recognized and the Family Service Organization was requesting that it be allowed to continue what it had been doing.

The budget statement included several annexes. Annex A gave a description of the purpose and function of the agency. The general purpose was to "....render sympathy and trained service to families which have fallen below a normal level of existence, in an endeavor to help them regain a life of health, happiness and independence." I There followed, in language understandable to the lay person, a description of services given other than relief, and concluded with the following quotation, "First ascertain the immediate real need and render prompt assistance in meeting it; then try, carefully and sympathetically, to find and help remove the cause of that need." 2

\section{Ib1a. \\ 2 Ibid.}


The section on types of service explained that relief was given immediately if needed, then subsequent steps included such services as medical care, employment, vocational training, and all types of services which the agency gave at that time. "Salaries are not merely for 'administering rellef'; they represent the cost of all the services rendered to more than two thousand families a year."I

Under the section entitled. "The Visitor's Job" was an explanation of how the visitors were carefully selected and the special qualifications they were required to have, which included certain qualities of personality, health, and education, with experience in performing the above named services.

In discussing how the work was organized, it was stated that since it was not always possible for each visitor to use her own judgment, there were three district supervisors of ability and long experience in charge of the work; that the visitors had consultations with the supervisors dally; that the work of the supervisors was to help the visitors in solving the encountered dificulties; that the agency at that time had the same number of supervisors as it had seven or elght years before; that each one was supervising twice the number of visitors and three times the number of families as before;

\section{${ }^{1}$ Ibia.}


that a home economist advised visitors; that an InterC1ty Secretary handled hundreds of inquiries from other cities and cared for transients stranded in Louisville; and that all the work was under the direction of the Board of Directors of the Family Service Organization. Annex B consisted of a case story taken from the flles of the agency's records, which illustrated the situation of a deserted mother, who was in ill health and complicated by worry and mental strain, and how the services of the agency helped. An explanation was made also that a confidential relationship was maintained, and that in making a case illustration, names, dates, places, and all ldentifying information were changed so that no recognition of the family could be made. Annex $C$ included a comparison of Louisville with eight other cities of population between 175,000 and 406,000, and showed the separate amounts of expenditures by the Family Society and the city or county relief, the total of all such expenditures with the total amount and per capita amount. Using the same clties, there were also comparisons of the average case load per visitor and of the beginning and highest salaries paid the visitors.

Annex D contained a break down and explanation of Increases and decreases of each minor item, such as field expense, telephone, postage, and other operating expenses. 
Annex $E$ included in detail the estimated budget for 1925, the approved budget for 1924, and the actual and estimated expenditures for 1924, as shown in Table 15. Annex $\mathrm{E}$ also included the receipts or sources and amounts of income of the agency for the same periods, as shown in Table 16. As the fiscal year of the Community Chest ended on September 30, 1924, while the fiscal year of the Family Service Organization ended on December 3I, 1924, the actual expenditures of the agency through September 30, 1924, were used and the expenditures for the remaining three months were estimated, resulting in the amounts of the expenditures for 1924 as shown in Annex $E$ of the budget being part actual and part estimated. The same situation resulted in the amount of income received by the agency in 1924 as set forth in Annex E of the budget submitted to the Community Chest and as shown in Table 16.

The budget presented by the agency for the year 1925 to the Community Chest was one of the most complete and detailed budgets ever presented by $1 t$.

The budgets of the agency for the subsequent years of the perlod did not vary a great deal. Each year had some change in the details of presentation depending upon the emphasis the agency wished to show the Buaget Committee of the Community Chest as a particular need at the time. It was obviously important that a clear and comprehensive picture of the agency's financial 
TABIE 15

\section{BUDGET OF THE FAMIIY SERVICE ORGANIZATION} AS SUBMITTED TO THE COMMUNITY CHEST

$\frac{\text { Year } 1924}{\text { App. by }} \frac{1925}{\text { Act. \& Est. Com. }} \quad \begin{gathered}1925 \\ \text { Exp. }\end{gathered}$

Capital Account:

Furniture \& Equipment

Recora System

Total

Social Service:

Salaries (case workers) $\$ 37,245.00$ (clerical)

Field Expense

Total Social Service

Aaministrative \&

Operative:

Salaries

Telephones

Postage

Printing \& Office

Rent

Supplies

Repairs to furniture, etc.

Traveling Expenses

Insurance

Dues - Am. Ass'n.

Publicity

Auditing \& Accounting

Miscellaneous

Total Ad. \& Operative

Total (All except material relief)

Relief (Naterial):

Provisions

Clothing \& Shoes

Rent

Cash relief

Medical relief

Miscellaneous

Total Relief $6,490.00$

$\frac{3,130.00}{\$ 46,865.00}$

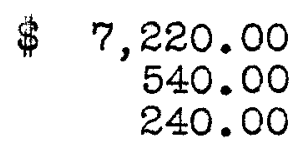

540.00

240.00

900.00

$2,558.00$

50.00

400.00

150.00

660.00

450.00

350.00

815.00

$14,333.00$

$63,768.00$

$\$ 16,000.00$

$2,625.00$

$6,730.00$

$1,800.00$ 700.00

$9,460.00$

$\$ 37,315.00$

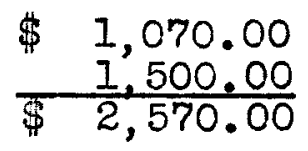

$\begin{array}{r}331.59 \\ 1.599 .78 \\ \hline 1,931.37\end{array}$

$\$ 31,849.93$ $5,544.49$

$\frac{3,123.34}{\$ 40,517.76}$

$\$ 6,197.73$

423.23

300.02

$\$ \quad 2,205.00$

$\frac{0.00}{\$ 2,205.00}$

$\$ 37,010.00$ $6,400.00$

3.960.00

䌮 $47,370.00$

838.12
$2,131.00$

3.11

79.88

76.40

460.00

0.00

0.00

631.40

$\$ 11,140.89$

$\$ 53,590.02$

$\$ 20,777.20$

2,881.21

$5,467.06$

$7,030.00$

329.52

$\frac{6,256.69}{742,742.46}$

$\$ 8,170.00$

540.00

350.00

900.00

$2,826.00$

10.00

450.00

125.00

868.00

200.00

450.00

720.00

\$15,744.00

$\$ 65,319.00$

\$20,000.00

$3,000.00$

$5,500.00$

$7,000.00$

500.00

$\frac{6,500.00}{42,500.00}$

Grand Total 
TABLE 16

\begin{abstract}
ESTIMATED INCOME OF FAMILY SERVICE ORGANIZATION FOR 1925 AS SHOWN IN BUDGET SUBMITTED TO THE COMMUINITY CHEST
\end{abstract}

\begin{tabular}{lcc} 
Year 1924 & \\
\hline Approved & Actual and & 1925 \\
by Budget & Estimated & Estimate \\
Committee & Income &
\end{tabular}

Recelpts:

Capital:

For Record System

$$
\$ 1,500.00
$$

$\$ 1,599.78$

萬

0.00

Return Revolving Fund 500.00

500.00 500.00

Total

$\$ 2,000.00$

$\$ 2,099.78$

$\frac{500.00}{\$ \quad 500.00}$

Operation:

Refunds:

Beneficiaries

$\$ 6,000.00$

$\$ 5,812.04$

\$ $6,000.00$

Miscellaneous refunds

$\frac{200.00}{\$ 6,200.00}$
53.61

$\frac{100.00}{6,100.00}$

Total

$\frac{53.61}{\$ 5,865.65}$

Community Chest

Allotment $92,633.00 \$ 87,510.55 \$ 101,069.00$

Child Welfare

0.00

773.27

0.00

On hand - beginning

of Period

0.00

9.71

0.00

Total receipts from

Community Chest $\$ 92,633.00 \$ 88,293.53 \$ 101,069.00$

Investments:

Interest on Bequests

$\$$

250.00

事

73.52

$\$ \quad 150.00$

Total Recelpts

$\$ 101,083.00$

$\$ 96,332.48$

\$107, 819.00 
needs be presented as practically all of its funds were derived from the Chest.

After the agency's affiliation with the Community Chest, it became necessary to establish a separate fund for the maintenance of the buildings, as such maintenance could not be paid from the allotment of the Chest. Accordingly, the House Fund was established in 1923 apart from the General Fund. Substantlally, all the income of this fund was received from rentals. Out of the General Fund, the Family Service Organization transferred to the House Fund an amount equivalent to a reasonable rental for that portion of its premises used by it in its work. Such amount, together with the rents it recelved from other agencies housed in the building, provided sufficient revenue to enable the organization to maintain its property.

In summary, the period of the Family Service Organization from 1923 through 1928 showed a change in the emphasis of the work. The service given was in the nature of preventive and constructive work.

In the period following World War I, unemployment was constantly on the increase, and the Family Service Organization, as others throughout the country, found lt difficult to meet the financial needs of its clients. The family agency became more and more "a pocket book" for financial needs and received most of the "overflow" from other agencies whose functions were 
more clearly defined. Emphasis was placed on the need for a public relief program. Studies showed that in many other cities, a public relief program was already started and certain categorical groups, such as chron1cally 1ll, unemployed, the aged and infirmed, and such other groups, were being cared for by public agencles. The local family agency, while still defining Its function as a service agency, was forced to meet the more material needs. Case loads increased and funds were inadequate.

The Community Chest program expanded. Substantially all the funds of the Family Service Organization were derived from that source. With the development of the Chest with its affiliated agencles working together, and the need of all agencies to co-operate in an endeavor to meet the problems, the period showed a general movement toward federation, standardization, and unification, a general trend throughout the country.

Emphasis was placed on budget-making and presentation to the Budget Committee of the Chest. OnIy through an understanding by the Chest of the financial needs and limitations of the agency could the budget as presented by the agency be approved. For this reason, the budgets during the perlod were very clear, detalled, and comprehensive. With the budget was given a concise picture of the agency's work with case illustrations. 
98

In spite of the period being one of confusion, of limitations in meeting the needs of the public, and the inability to adhere to its function as defined by the agency, the agency was able, nevertheless, to maintain a certain amount of security and to see clearly ahead so as not to lose sight of its goal. 


\section{CHAPTER IV}

THE FAMILY SERVICE ORGANIZATION, 1929-1942 
CHAPTER IV

THE FAMILY SERVICE ORGANIZATION, 1929-1942

The period 1929 through 1942 of the Family Service Organization actually contained two aistinct perioas; i.e., 1929 through 1938, and 1939 through 1942. Actually, the latter period did not end with 1942, but continues as another episode in that period of the history of the agency and runs on into its future. The latter period was too short and indefinite to be considered as a separate chapter. It is Indefinite because the things which took place and are now taking place were and are only indications of trends and cannot as yet be seen in perspective. As the latter period merges with the present and may proceed into the future, one experiences difficulty in viewing and examining the period objectively on a factual basis as a separate phase in the history of the agency. During the preceding period, unemployment appeared to have steadily increased. The "stock market crash" occurred in the latter part of 1929, prec1pitating and marking the beginning of the "great depression". Thereafter, unemployment progressively increased and reached abnormal proportions in the early thirties. The agency already overwhelmea with the burden it was forced to bear, was called on to meet a still greater 
emergency. Nationally, pressure was being exerted to procure the Federal Government to step in and give assistance as the private agencies found themselves unable to carry the load. Congress failed to pass any leglslation in 1930 or 1931; however, in February, 1932, Congress authorized distribution of Government-owned wheat and cotton. Federal assistance in the form of loans to States was initlated in 1932. In May, 1933, the Federal Emergency Relief Administration came into existence. The operation of that Administration became effective in August, 1933. That organization was the means of dispensing public funäs to public agencies which were to administer them. Through the Federal Emergency Relief Administration, though an emergency and considered temporary agency, came a defining of the controversial matter of the division between public and private responsibility. The beginning of a general public relief program emerged in the early thirties as an emergency measure and not planned as a permanent program.

As the depression progressed and public relief assumed aspects of permanency, the need of a well defined public relief program was realized. Accordingly, the period of 1935 to 1939 was in direct contrast to the early years of the depression; a more permanent program was developed. The Federal Government assumed responsibility for certain catagories of need, and pro- 
vided for the unemployed through a federal work relief program. Grants in aid to the States under the Social Security Act were provided in the program of public assistance to the blind, the aged, and the needy chilaren. Locally, the Family Service Organization in 1929 decided that action from that agency and the Community Chest was necessary to secure funds from the Clty to meet the emergency needs for rellef. They also:

recommended the prompt establishment of an adequate public employment bureau by the city and federal authorities to attack the placement problem as jobs open up, to complle figures on peak and dull season of employment, and to keep business and both local and federal authorities appraised of conditions in the future so that plans may be made in time to avert or lessen repeated emergencies. 1

In February, 1930, it was necessary for the Family Service Organization to ask the Community Chest to make a special request for funds. In May, 1930, the situation had become so acute that an open letter was sent to the newspapers telling of the plight of the agency. The results from this letter were splendid, but the money thus received only assisted the agency in meeting an emergency. In February, 1930, it was necessary to close out all cases which were service only and to continue to carry cases where relief was necessary, giving what little service it was possible to give under

${ }^{I}$ Minutes of Directors' Meeting, December 17, 1929. 
the circumstances. This step proved again the flexibility of the private agency in meeting the needs of the time; although it was a drawback to the agency's progress and completely opposed to the agency's function. In November, 1930, an emergency department was established within the agency to handle the emergency load. No case histories at all were taken on those families.

Although nothing of an organized nature had, by that time, been attempted by the municipal government, consideration and study was given to the problem by the Board of Trade. The Mayor was active in securing additional funds for the private agencies, and assurance. was given that the city would assume its share of responsibility in handling the emergency unemployment situation. The municipal government, then recently re-organized, had established a Department of Welfare, and the first problem of the Director was to formulate plans for alleviating the unemployment situation. During the summer of 1930, studies were made of the emergency measures of other clties, and by fall, the conclusion was reached that a work-relief program was the most practical solution. In the meantime, the Community Chest, pressed by the increasing demands from the Family Service Organization, presented the critical unemployment situation to the Board of Trade for immediate action. A meeting of the local business men and representative citizens was 


\section{4}

called. An Unemployment Committee of the Board of Trade was organized with the appointment of three of the members as an Executive Committee; 1.e., the Mayor, an officer of the Board of Trade, and the President of the Community Chest. The Mayor presented to the Unemployment Committee the plan which the Director of Welfare had formulated. The plan was approved and the Director of Welfare was placed in charge. In November, 1930, the plan was presented to the Board of Trade and subsequently put into effect.

The main items in the plan included:

1. A Central Bureau as headquarters;

2. A municipal relief committee, including the Mayor, the president of the Board of Aldermen, and the Director of Welfare, to which was appropriated all city funds for emergency relief. The preliminary appropriation of $\$ 25,000$ was placed at the aisposal of the Unemployment Committee by the Municipal Relief Committee to initiate work relief for needy unemployed. The work was of a "Iight labor" type aistributed as follows:

(a) In city departments and cityowned institutions, work which would not ordinarily be undertaken because of lack of funds;

(b) In private and non-profit making and charitable institutions, which would be expected to furnish the men carfare and one meal a day. I

The clty appropriations were to be made in small amounts rather than in a lump sum so that publicity following a large appropriation would not at-

${ }^{1}$ Joanna Colcord, Emergency Work Relief, (New York: Russell Sage Foundation, 1932), p. 119. 
tract needy families from all over the state. On November 11, 1930, the Emergency Unemployment Bureau of the Unemployment Committee, later known as the Municipal Relief Bureau and still later as the Municipal Bureau of Social Service, officially opened. A registration of the unemployed was conducted prior to the opening of the Bureau. Volunteer clerical workers were assigned to register the unemployed persons in fire and police stations. No comprehensive census of the unemployed was undertaken. Only heads of destitute families were registered.

The Director of Welfare felt that, in order for the Bureau to work successfully, an investigation should be made by trained social workers, and that the Bureau should not depend upon the existing social agencies for this. A competent supervisor and five trained and experienced workers were secured. Three more with some training were added. Seven persons were employed for clerical work.

Those registrants who were clearly ineligible for work relief were eliminated. Work relief jobs were given only to men who had dependents under sixteen years of age, living with their families and having an income of less than thirty dollars a month. The Family Service Organization stationed some of its staff at the Municipal Relief Bureau so that 
necessary cases for direct relief could be given immediate attention. The Bureau did not give work relief to any of the persons under the care of the Family Service Organization. Cases of the unemployed active with the private agency were transferred to the public agency.

The first step in the assignment of jobs was the securing from prospective employers the number of men needed, the length of employment, and the nature of the work. The social worker then selected those to be assigned, and notified them, by mail or by a home visit, to come to the Bureau. They were given a work card with the necessary instructions. The applicant signed the work card and presented it to the foreman on the job; the foreman filled out the portion of the card showing the time worked, entered comments on the work record, signed and returned the card to the worker. The foreman also sent the Bureau a pay roll list showing the number of hours each man worked.

The wages each man received were on the basis of two and three day shifts at thirty cents an hour. Most of the work was on the basis of eight hours a day, the maximum pay per week thus being $\$ 7.20$. The men were given street car tokens if necessary. When the pay was recelved, the men signed their work cards, turned them in, and were directed to come back in two days for another card.

The work included no large construction jobs, 
but was mainly clean-up and repair work for city departments and private institutions. The cost of materials and supervision was met by the institutions or departments for which the work was done. From November 11, 1930, to April 18, 1931, \$114,536.00 was paid in wages and transportation of the workers by the Bureau; $\$ 111,631.00$ of that sum represented wages paid during the entire period. Transportation costs amounted to $\$ 2,905.00$. Of the amount of money spent for wages, \$25, 485.00 was for work in private institutions, and $\$ 86,146.00$ was for work in c1ty departments. The cost of administration of the Municipal Relief Bureau was charged against the regular budget of the Department of Public Welfare.

Of interest was the development of the work relief laea. Miss Colcord ${ }^{I}$ pointed out that work instead of alms for the needy was stressed as early as 1711 in the Hamburg system of public charity in Germany. Work rooms were established, and supplies of flax were given the poor for spinning in their own homes. The use of the unemployed on public improvements was used in England throughout the nineteenth century.

The philosophy of work relief was different, however, from that which prevailed earlier in England and in this country. As was mentioned in the early 
periods of the Louisville Charity Organization Society and the Associated Charities, work was relied upon as a deterrent to the willfully idle and the "work test" developed. Quite often it consisted of some useless task such as wheeling stones from one side of the yard to another, or digging holes and filling them again. Like all forced labor, the results were never very valuable and were often harmful. As social work developed further skills in dealing with human beings, the work test in its cruder forms was discarded.

In the past during times of industrial depression and unemployment, many plans were developed for "made work" for the idle. The philosophy behind those were quite different from the work test. It was taken for granted that many citizens were idle not because they wanted to be. It was better for their morale if they were provided with an opportunity to earn necessities rather than given out-right relief. However, the history of "made work" was disappointing. Work rooms were hastily opened, and the work usually was not particularly useful or of permanent value. The recipients regarded it as it really was - "sugar coating for relief". The last depression, when "made work" was discouraging, was in 1914 and 1915. The same winter, however, two private social agencies experimented with new forms of made work. One, the New York Association for the Improvement of the Condition of the Poor, entered 
Into arrangements with one of the large city parks to employ able-bodled men at a regular wage. The money for the wages came from the Association. The Associated Charities of Minneapolis secured the privilege of "logging up" some land which had been inundated by the Mississippi River. Cllents were paid wages (instead of relief) for their work. Those projects were real work of a useful nature, and performed under the same conditions as though the men had been hired in the labor market.

The "made work" 1dea of the Municipal Relief Bureau in 1930 was based on that philosophy. There were many drawbacks to the use of public works as unemployment relief. The cost was greater, and the work performed was less satisfactory. There was also difficulty in the assignment of work to those who most urgently needed it. Rellef wages adversely affected other wages. Rellef work was many times the anticipation of work which would have later been required. Relief work, extending over considerable periods of time, had an unwholesome effect upon the workers.

During its first period of operation, the Municipal Relief Bureau was not equipped, financially or with staff, to perform the whole program. It was necessary for the Frmily Service Organization to help carry the burden. Appropriations were given to the agency, sometimes from the city and county, sometimes from the city 
alone, either airectly to the agency or through the Community Chest. When the Municipal Relief Bureau closed its operations for the first period in the spring of 1931, the entire burden again fell upon the Family Service Organization. The unemployment relief cases were assumed by the agency on the basis that they were the public responsibility and would later be taken over by the city. Each year until 1933, the Municipal Relief Bureau operated only auring the fall and winter months; the agency had the full burden during the summer months.

During the time the agency carried all or part of the public responsibility, public funds were granted to the agency. In 1931, Miss Harriet I. Tynes of the Family Service Organization made a study of the relationship between public and private agencies with special reference to public subsidies to private agencies. Miss Tynes reported that the "subsiay system" had been in use in the United States for over a hundred years. AlI subsidies came about "by accident". A private agency was usually organized to meet a particular need, and after experimentations were made and the need recognized, provision was made for the continuation of the work. As the governmental division had the responsibility, but no organization through which to administer to such a need, grants were made to the private agency. The 
system was perpetuated by the fallure to formulate future plans. The results of the study of subsidies for more than a century indicated that such a system was disadvantageous except as an emergency measure with a specified time limit. The arguments against the subsidy system were based on facts which were divided into two groups; 1.e., those which affected the general welfare of the community, ana those which concerned the private agency itself. In the first group were:

1. Subsidies prevent or retard the development of public welfare departments.

2. Subsidies waste public funds.

3. Subsidies open the way for pernicious politics. $1^{2}$

The aspects of the subsidy system which affected the agency itself were:

1. A subsidy is often a poor business arrangement for the private agency.

2. Subsiaies subject the private society to the danger of political interference.

3 . Subsidies hinder progress in the private agency and endanger the introduction of new and improved methods.

4. Subsiaies lessen private contributions. ${ }^{2}$

In view of the disadvantages of the system, various states stopped such practice. As an alternative, a form of subsidy called the per captta system was used. That was not a solution of the problem, but was regarded as a good arrangement for transition. The system

$I_{\text {Harriet L. Tynes, The Relationshlp Between Pub- }}$ I1c and Private Agencies, (mimeographed). On file at Family Service Organization.

2

IbId. 
was best understood when explained in contrast to the older method of subsidizing.

Under the old or "Iump sum" subsidy plan, the public authorities made a grant of a definite lump sum to a private agency. The private agency spent the money as it thought best, and then, as time or clrcumstances required, requested more.

Under the per capita arrangement, no fund was granted at any one time to a private agency. Instead, the public authorities, through an authorized administrator, usually the Department of Welfare, agreed to pay the private organization a definite sum for each case under its care. The public department stipulated the number and type of cases for which it would pay. The private organization billed the public department regularly for services rendered in each specific case, including in the bill the administrative costs to the private agency, as well as the actual relief given to the client.

The advantage of the per capita over the lump sum system were:

1. It is a definite business arrangement for each specific case.

2. The public authority admits and assumes the responsibility for certain designated classes.

3. Because of this fundamental admission and assumption of responsibility, the development of a public department to do its own work is facilitated.

4. The public administrative authority 


\section{3}

is enabled to prevent duplication in

the expenalture of public funds.

5. The public authority can prescribe methods and uphold standards of treatment

for the cases for which it pays. 6 . The public authority collects valuable statistical information. 7 . Some of the worst features of the political patronage are obviated because grants are not made to the private organization but to a public administrative body, to be expended at its aiscretion for definite services. There are, therefore, two checks by public authorities in expenditure of public funds. 1

The per capita system of subsidizing was not the method used locally during the depression years. While the Family Service Organization recognized the evils of the lump subsidy, there was nothing that could be done about it at the time. The agency continued to be on guard and constantly brought pressure to bear for public responsibility toward certain groups of families. In the fall of 1933, the Municipal Relief Bureau began recelving some federal funds and operated during the entire year. Many of the unemployment reIlef cases were taken care of by the public agency, but there were a large number of borderline cases in that group which were refused by the public agency and of necessity were cared for by the private agency. In addition, the Family Service Organization continued to care for the large group of long-time relief families among which were the unemployable, the blind, the aged, and

\section{${ }^{1}$ Ib1a.}


the Mothers' Aid families. All of those were the responsibility of the public agency, but for which no plan had been made. For the care of such families, the city and county, or city alone, continued to pay subsidies to the private agency. The period of the 1930's or the "depression years" was known to the Family Service Organization as the period of public subsidies. Table 17 and Chart $\mathrm{V}$ show the income of the agency during the period, with amounts received from the Community Chest, public funds, gifts in kind, and other income of the agency. In 1937 and 1938, unknown amounts of public funds were received by the agency through the Community Chest. Subsidizing was discontinued after 1938. The proportion of public subsidies was fairly small in 1929 and 1930, and increased rapidly in the early 1930's, through 1936. The highest amount of money spent by the agency in its entire existence was in 1932, and was approximately one hundred twenty times the amount spent in 1884, the first year of the agency. With the exception of the year of 1933, the largest amount received by the agency from any single source was received from the Community Chest; although the amount of public subsidies during the period was almost as large as the amount received from the Chest. Actual amounts of other income of the agency did not vary a great deal, but increased in proportion to the total income, resulting from a aecrease in the total amount of income. Gifts 
TABLE 17

SOURCES OF INCOME OF THE FAMILY SERVICE ORGANIZATION OF LOUISVILLE, KENTUCKY, 1929 THROUGH 1942

\begin{tabular}{|c|c|c|c|c|c|}
\hline Year & $\begin{array}{l}\text { Total } \\
\text { Income }\end{array}$ & $\begin{array}{c}\text { Community } \\
\text { Chest }\end{array}$ & $\begin{array}{l}\text { Public } \\
\text { Funds }\end{array}$ & $\begin{array}{c}\text { Gifts in } \\
\text { Kind }\end{array}$ & $\begin{array}{l}\text { Other } \\
\text { Income }\end{array}$ \\
\hline $\begin{array}{l}1929 \\
1930 \\
1931 \\
1932 \\
1933 \\
1934 \\
1935 \\
1936 \\
1937 \\
1938 \\
1939 \\
1940 \\
1941 \\
1942\end{array}$ & $\begin{array}{r}\text { \$168, 721.70 } \\
178,262.73 \\
294,720.11 \\
362,942.44 \\
284,323.70 \\
279,593.95 \\
268,541.51 \\
203,345.94 \\
167,720.74 \\
114,199.09 \\
97,287.27 \\
92,842.24 \\
90,501.58 \\
87,529.70\end{array}$ & $\begin{array}{r}\$ 123,068.14 \\
135,077.43 \\
155,242.08 \\
214,018.86 \\
94,083.99 \\
135,960.30 \\
142,099.60 \\
110,749.51 \\
153,507.68 \\
96,962.64 \\
83,252.47 \\
82,456.08 \\
78,665.80 \\
76,833.52\end{array}$ & $\begin{array}{r}27,500.00 \\
15,500.00 \\
117,063.26 \\
127,000.00 \\
155,357.33 \\
99,626.64 \\
105,868.41 \\
73,000.00 \\
\text { N.A. } \\
\text { N.A. } \\
0.00 \\
0.00 \\
0.00 \\
0.00\end{array}$ & $\begin{array}{r}0.00 \\
0.00 \\
0.00 \\
2,579.85 \\
17,943.01 \\
23,218.33 \\
6,950.95 \\
8,993.85 \\
3,377.90 \\
3,073.98 \\
4,181.82 \\
112.11 \\
13.15 \\
76.51\end{array}$ & $\begin{array}{r}\$ 18,153.56 \\
27,685.30 \\
22,414.77 \\
19,343.73 \\
16,939.37 \\
20,788.68 \\
13,622.55 \\
10,602.58 \\
10,835.16 \\
14,162.47 \\
9,852.98 \\
10,274.05 \\
11,822.73 \\
10,619.67\end{array}$ \\
\hline
\end{tabular}


CHART V

SOURCES OF INCOME OF THE FAMILY SERVICE ORGANIZATION OF LOUISVILLE, KENTUCKY, 1929 THROUGH 1942

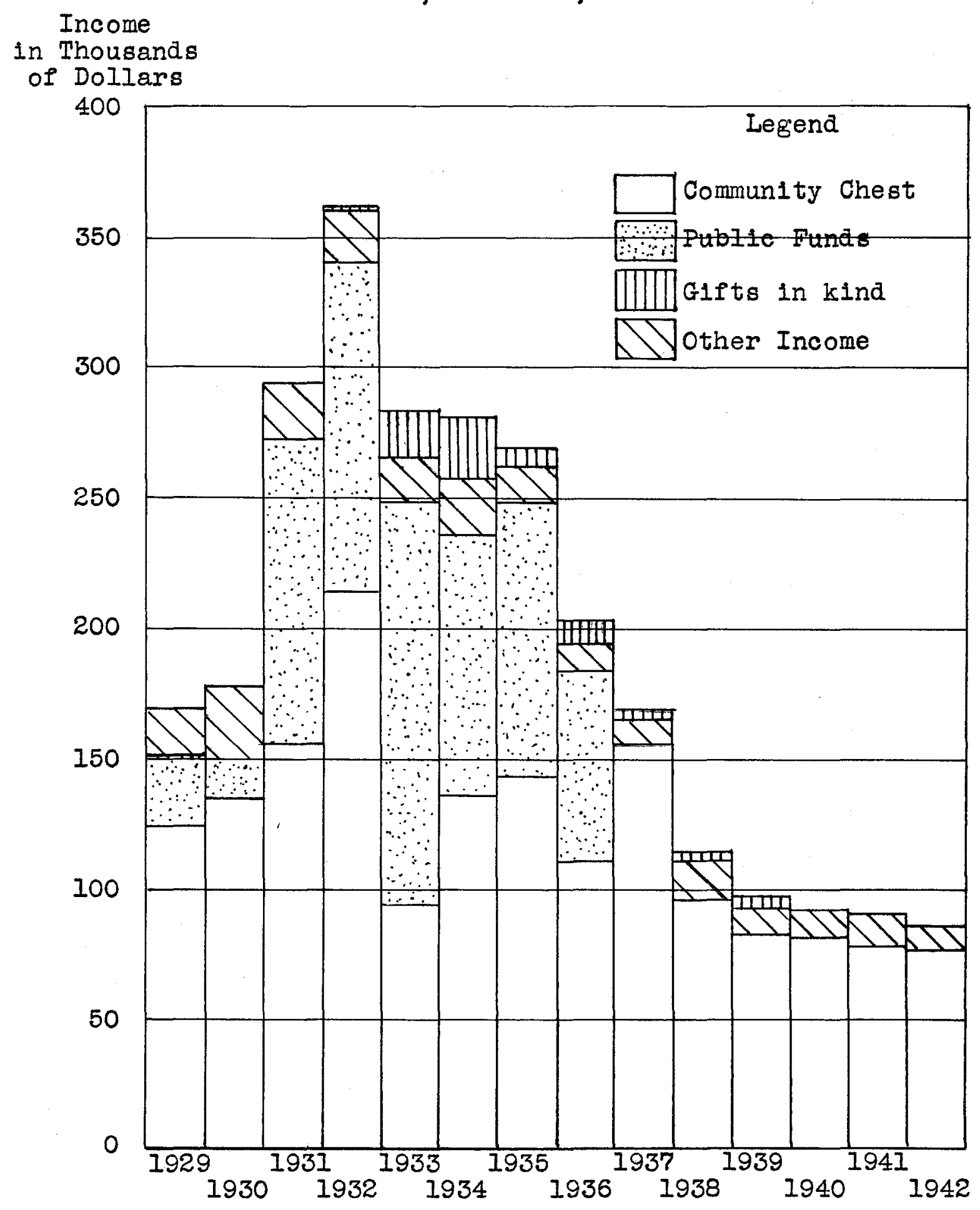




\section{7}

in kind consisted of actual commodities, such as clothing and food, given to the Family Service Organization to distribute to the families under its care. Such gifts were given by the Government, church groups, and individuals. For its records, the agency fixed the then current monetary value on each item recelved. In the year of 1936, the funds received from public sources dropped considerably; although the figures are not known for the years of 1937 and 1938, small amounts were given through the Community Chest allotment. Public subsidies were discontinued after 1938. During the years of 1935, 1936, 1937, and 1938, the public agency assumed more and more of its responsibility, probably a result of efforts made by the Family Service Organization. Beginning in 1935, the first group of families; 1.e., the Mothers' Aid families, were transferred to the public agency. Other groups were transferred in subsequent years until the final group was accepted in 1938. The name of the public agency was changed to the Municipal Bureau of Social Service. Although the federal program gave grants to the States for ald to the dependent children and the blind, Kentucky was late in establishing the program, and therefore had not progressed as far as other states. The Municipal Bureau of Social Service was unable to meet adequately the needs of lts clients, even though times were prosperous. Those facts could indicate a fore- 
shadowed future pressure on the private agency should times get worse and public relief become more inadequate. The years 1938 and 1939 saw the Family Service Organization in a period of transition and a re-defining of lts function as one of service to individuals and to families. The period of 1939 through 1942 was a short and recent one. Its brevity and proximity to the present makes ineffectual an extended discussion of the period. It may be compared with the period of the depression. The depression years were ones of emergency and confusion. The post-depression years have shown permanence and clarity. The transitory period of the Family Service Organization came a few years later than in other cities similar to Louisville; accordingly, the agency could benefit by the experience of agencies in the other cities. As can be seen by Table I7, the income of the agency was fairly static after 1938. The source of income consisted mainly of the allotment from the Community Chest with some other income. The amount from each of such sources remained fairly constant after 1938. Other income included interest from investments, special gifts, discounts from merchandise purchased, refunds from benefitted individuals, and rents. Rents and special gifts comprised the largest amounts of the group. During the early 1930's, discounts were a substantial amount, but after 1939, they were almost negligible. In recent years, 
the grocery requisition, on which some of the discount was given, was not used to any great extent. The giving of money to the individual who then makes his own purchases is the more approved method.

Table 18 and Chart VI show the proportion of money spent for relief in comparison to the total amount of money spent. At the beginning of the 1930's, the percentage of money spent for relief rose very sharply in comparison to the total amount of money spent. As has been previously stated, even this amount of money was inadequate to meet the needs of the clients. The first half of the decade showed approximately three-fourths of the money was spent for relief. Under such a practice, the agency would be consldered as a relief agency by the general public instead of a service agency. The first arop of any consideration in the proportion of rellef occurred in 1936, after the first large group of famlies was transferred to the public agency. Thereafter, there was a steady decrease, larger reductions occurred in 1938 and 1939, the year during and the year after the last groups were transferred to the Municipal Bureau of Social Service. Obviously, the need for financial relief was less in 1941 and 1942 as a result of the war with its accompanying abundance of jobs and higher wages. At the present time, the agency is able to give adequate relief in contrast to earlier times when the relief was inadequate. It is interesting to note the change in the 
TABLE 18

RELIEF EXPENDITURES AND OTHER EXPENDITURES OF THE FAMILY SERVICE ORGANIZATION OF LOUISVILIE, KENTUCKY, BY AMOUNT AND PERCENT, 1929 THROUGH 1942

Year $\begin{gathered}\text { Total } \\ \text { Expenses }\end{gathered} \frac{\text { Relief Expenses }}{\text { Amount }} \frac{\text { Other Expenses }}{\text { Percent }}$

$1929 \$ 165,894.32 \$ 82,066.17 \quad 49.5 \$ 83,828.15 \quad 50.5$

$\begin{array}{llllll}1930 & 185,580.58 & 107,642.28 & 58.0 & 77,938.30 & 42.0\end{array}$

$\begin{array}{llllll}1931 & 289,283.13 & 202,681.82 & 70.1 & 86,601.31 & 29.9\end{array}$

$\begin{array}{llllll}1932 & 361,941.98 & 272,191.92 & 75.2 & 89,750.06 & 24.8\end{array}$

$\begin{array}{llllll}1933 & 284,659.61 & 208,501.65 & 73.2 & 76,157.96 & 26.8\end{array}$

$\begin{array}{llllll}1934 & 280,253.88 & 211,602.56 & 75.5 & 68,651.32 & 24.5\end{array}$

$\begin{array}{llllll}1935 & 262,641.35 & 194,988.82 & 74.2 & 67,652.53 & 25.8\end{array}$

$\begin{array}{llllll}1936 & 202,575.08 & 137,861.41 & 68.1 & 64,713.67 & 31.9\end{array}$

$1937 \quad 169,691.15 \quad 106,892.79 \quad 63.0 \quad 62,798.36 \quad 37.0$

$\begin{array}{llllll}1938 & 112,751.05 & 56,565.25 & 50.2 & 56,185.80 & 49.8\end{array}$

$1939 \quad 97,425.23 \quad 42,074.79 \quad 43.2 \quad 55,350.44 \quad 56.8$

$\begin{array}{llllll}1940 & 90,792.50 & 38,404.61 & 42.3 & 52,387.89 & 57.7\end{array}$

$\begin{array}{llllll}1941 & 88,425.99 & 35,915.80 & 40.6 & 52,510.19 & 59.4\end{array}$

$\begin{array}{llllll}1942 & 86,251.67 & 32,559.92 & 37.7 & 53,691.75 & 62.3\end{array}$ 
CHART VI

RELIEF EXPENDITURES AND OTHER EXPENDITURES OF THE FAMILY SERVICE ORGANIZATION OF IOUISVILLE, Expenditures KENTUCKY, 1929 THROUGH 1942

in Thousands

of Dollars

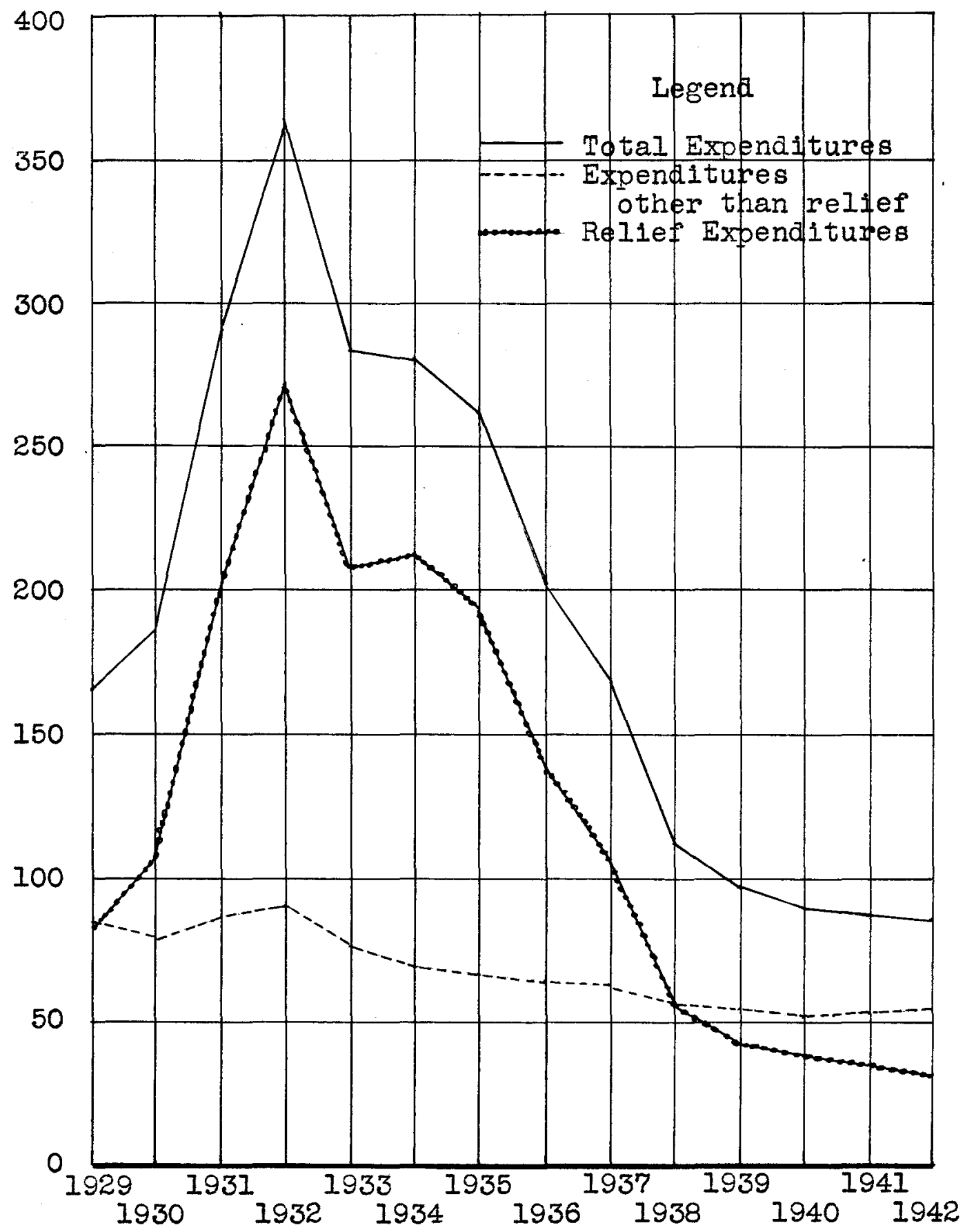


nature of the relief. Previously, relief consisted mainly of food and clothing. Now, it includes anything which would aid in the adjustment of the individual or family. Such items might include the purchase of furniture, tuition at school, or payment of a debt.

Table 19, showing the proportion of money spent on salaries, naturally reflected the condition represented by Table 18 and Chart VI. As the relief expenditures mounted, salaries also decreased in proportion to the total expenses. When more money was needed for relief, it meant that less was avallable for salaries. The agency fought against cutting the salaries of the workers. The Community Chest was insistent upon that, but the agency felt that by cutting salaries, it would lower the standards of the agency, and hence the value of the work would be lowered. Then, too, by decreasing salaries, a great many of the skilled workers would. leave to take jobs elsewhere which paid better. With a lower salary than other agencies, probably the only avallable workers would be untrained, inexperienced ones. Those replacements might represent a saving with regard to actual money spent but would be more expensive in actual cost of results produced and cost to the agency in training them. In withstanding the demands of the Community Chest relative to cutting the workers' salaries, the agency was outstanding in maintaining initiative and freedom. At first, when cuts were made 
TABLE 19

SAIARY EXPENDIIURES OF THE FAMILY SERVICE ORGANIZATION OF LOUISVILIE, KENTUCKY, BY AMOUNT AND PERCENT, 1929 THROUGH 1942

\begin{tabular}{llcc} 
Year & Total & \multicolumn{2}{c}{ Salaries } \\
\cline { 3 - 4 } 1929 & Expenditures & Amount & Percent \\
1930 & $\$ 165,894.32$ & $\$ 64,143.92$ & 38.7 \\
1931 & $185,580.58$ & $61,375.56$ & 33.1 \\
1932 & $289,283.13$ & $68,075.97$ & 23.5 \\
1933 & $361,941.98$ & $71,401.86$ & 19.7 \\
1934 & $284,659.61$ & $61,343.80$ & 21.5 \\
1935 & $280,253.88$ & $54,364.57$ & 19.4 \\
1936 & $262,641.35$ & $53,381.00$ & 20.3 \\
1937 & $202,575.08$ & $52,195.56$ & 25.8 \\
1938 & $169,691.15$ & $49,474.09$ & 29.2 \\
1939 & $112,751.05$ & $46,481.71$ & 41.2 \\
1940 & $97,425.23$ & $45,527.00$ & 46.7 \\
1941 & $90,792.50$ & $43,312.59$ & 47.7 \\
1942 & $88,425.99$ & $43,244.86$ & 48.9 \\
& $86,251.67$ & $44,431.73$ & 51.5
\end{tabular}


to the agency in the Community Chest allotment, a letter was sent stating which items should be decreased. The agency was firm in its belief that while the Community Chest had power to decide on the total amount of money to be allotted, it could not dictate how the money should be spent. In recent years, the Community Chest made no attempts to indicate how Family Service Organization funds should be spent. In addition to this situation, the agency made a contribution to the community in allowing the case supervisor and two senior workers to go to the public agency in order to help establish standards of the public agency. That was worthwhile as it resulted in later benefits to both agencies. Table 19 shows a stablization of proportion of money spent for salaries in the post-depression years. In 1942, slightly over half of the money spent was for salaries.

Throughout the years, the agency continued to stress the value of the trained worker. Even when the case loads were heavy, opportunity was given and the workers were encouraged to secure additional training. At first, such training was possible through the Sociology Department of the University of Louisville. Time off was given for classes during the regular school semesters. During the summer, two weeks were given, one with pay, in addition to the regular four weeks' 
vacation, to enable a worker to take a six-week's course at some university or school of social work outsiae the city. In 1937, the Graduate Division of Social Administration of the University of Louisville was approved by the American Association of Schools of Social Work. Workers from the agency continued to secure adaitional training. Further development of trainIng for the workers was secured through attendance at National Conferences and Regional Institutes, for which a week with pay was given. In addition to that, students from the Graduate Division of Social Administration took their field work at the agency. That enabled the more experienced workers at the Family Service Organization to secure supervisory training and experience by supervising such students. The "trained worker" at the Family Service Organization became a professional person. In 1930, a regulation was adopted making it mandatory that a prospective staff member be a graduate of a university or college, possess a bachelor's degree, and have pursued some courses in the field of sociology or social work. By 1936 and 1937, the standards of the "trained" worker in the agency had been raised still higher. Each prospective staff member was required to have had one year's graduate work in a school of social work. By 1942, the prospective worker was required to be a graduate of a school of social work or have two years of graduate work in such a school. A comparison of the educational 
qualifications of the workers of the agency in 1929 with those in 1942 is shown in Table 20. In 1929, there was no worker who had any graduate-school training. Of the seven with two years graduate work in 1942 , all but two had master degrees. Those two had completed all work for a master's degree with the exception of the writing of theses. The 1929 staff included eight additional workers, two of whom had no college education.

TABLE 20

EDUCATIONAL QUALIFICATIONS OF WORKERS OF THE FAMILY SERVICE ORGANIZATION OF LOUISVILLE, KENTUCKY, IN 1929 AND 1942

Amount

High School only

Two years College only

College Graduate

College Graduate plus 1 year Graduate work College Graduate plus 2 years Graduate work
1929

1942

$1 \quad 0$

30

80

$0 \quad 5$

$0 \quad 7$

In contrast to the detailed budget for 1925 discussed in Chapter III ${ }^{1}$, the budget for 1944 was made in a simpler form, but gave a clear, conclse picture of the problems which confronted the agency. The introductory page presented the picture of increasing problens

I $_{\text {Supra. , pp. } 86-96 .}$ 
intensifled by World War II. Simple explanations were made defining the outstanding problems which were brought to the agency, and which included family disorganization, family financial problems, problems of youth, and problems induced by industrial changes. Services given by the agency included family counseling, services to young people, homemakers' services, and services to draft and induction boards. All those services required special skills of the caseworkers.

The amount for relief requested by the agency showed a decrease, but provided adequately for the famiIles under its care. Table 21 shows the actual expenses for 1942, the allowed budget for 1943, the actual expenses for 1943, the budget request for 1944, and the increases or decreases.

Included in the budget, also, was a list of the staff members and for each appeared the annual salary allowed for 1943, the actual and estimated salaries for 1943, the annual request for 1944, and the monthly rate for the 1944 request.

The budget concluded with the general qualifications of the professional staff and a list of the specific courses and institutes taken from the personnel records of one of the district supervisors and of one of the case workers. It was pointed out that masters' degrees and courses seemed far removed from helping people but such courses and institutes indicated the preparation 
TABLE 21

BUDGET EXPENDITURES OF THE FAMILY SERVICE ORGANIZATION OF LOUISVILLE, KENTUCKY, FOR 1944 AS PRESENTED TO THE COMMUNITY CHEST

\begin{tabular}{|c|c|c|c|c|c|}
\hline & $\begin{array}{c}\text { Actual } \\
\text { Expenses } \\
1942\end{array}$ & $\begin{array}{l}\text { Allowed } \\
\text { Budget } \\
1943\end{array}$ & $\begin{array}{c}\text { Actual } \\
\text { Expenses } \\
1943\end{array}$ & $\begin{array}{l}\text { Budget } \\
\text { Request } \\
1944\end{array}$ & $\begin{array}{l}\text { Increases } \\
\text { and } \\
\text { Decreases }\end{array}$ \\
\hline $\begin{array}{l}\text { Salaries } \\
\text { Rent }\end{array}$ & $\begin{array}{r}\$ 41,235.93 \\
2,921.76\end{array}$ & $\begin{array}{r}\$ 43,902.50 \\
2,921.76\end{array}$ & $\begin{array}{r}\$ 43,902.50 \\
2,921.76\end{array}$ & $\begin{array}{r}\$ 47,390.00 \\
2,921.76\end{array}$ & $+\$ 3,487.50$ \\
\hline Insurance & 77.19 & 105.87 & 81.07 & 70.03 & 11.04 \\
\hline Repairs & 157.75 & 125.00 & 125.00 & 125.00 & \\
\hline phone & 782.39 & 748.8 & 791.24 & 791.24 & \\
\hline Office Supplies & 702.11 & 375.0 & 375.00 & 375.00 & \\
\hline age & 239.52 & 229. & 229.90 & 229.90 & \\
\hline $\begin{array}{l}\text { Carfare } \\
\text { Auto Expense }\end{array}$ & 420.80 & 538.0 & 515.40 & 400.00 & 115.40 \\
\hline $\begin{array}{l}\text { Auto Expense } \\
\text { Jonference }\end{array}$ & 576.39 & 600.0 & 600.00 & 600.00 & \\
\hline Expense & 216.23 & 300.00 & 300.00 & 300.00 & \\
\hline ellef & $28,793.93$ & 32,000 & 31,805 & 29,400 & $-2,405.48$ \\
\hline 1cations & 112.50 & 60 & 60.00 & 60.00 & \\
\hline $\begin{array}{l}\text { Interpretation } \\
\text { Audit }\end{array}$ & 121.24 & $\begin{array}{r}75.00 \\
190.00\end{array}$ & $\begin{array}{r}75.00 \\
190.00\end{array}$ & $\begin{array}{r}75.00 \\
190.00\end{array}$ & \\
\hline Dues & 535.00 & 585. & 585.00 & 610.00 & 25.00 \\
\hline Bond Premium & 42.50 & 37. & 42.50 & 42.50 & \\
\hline Miscellaneous & $\frac{7.98}{9777332}$ & $\frac{25.00}{300}$ & $\frac{25.00}{20.0}$ & $\frac{25.00}{307}$ & \\
\hline Total & $\$ 77,133.22$ & $\$ 82,819.37$ & $32,624.85$ & $\$ 83,605.43$ & 980.58 \\
\hline
\end{tabular}


TABLE 22

BUDGET OF INCOME OF THE FAMILY SERVICE ORGANIZATION OF LOUISVILLE, KENTUCKY, FOR 1944 AS PRESENTED TO THE COMMUNITY CHEST

\begin{tabular}{|c|c|c|c|c|c|}
\hline & $\begin{array}{l}\text { Actual } \\
\text { Income } \\
1942\end{array}$ & $\begin{array}{l}\text { Estimated } \\
\text { Income } \\
1943\end{array}$ & $\begin{array}{c}\text { Actual } \\
\text { Income } \\
1943\end{array}$ & $\begin{array}{l}\text { Estimated } \\
\text { Income } \\
1944\end{array}$ & $\begin{array}{l}\text { Increases } \\
\text { and } \\
\text { Decreases }\end{array}$ \\
\hline Miscellaneous & 157.31 & 135.00 & 153.03 & 100.00 & 53.03 \\
\hline Dividends & $1,098,05$ & $1,200.00$ & 987.45 & 958.40 & 29.05 \\
\hline Total Independent & $\$ 1,255.36$ & $\$ 1,335.00$ & $\$ 1,140.48$ & $\$ 1,058.40$ & 82.08 \\
\hline Community Chest & 76.833 .52 & $81.484 .37^{*}$ & 81.484 .37 & $82,547.03$ & $+1,062.66$ \\
\hline rotal & $\$ 78,088.88$ & $\$ 82,819.37$ & $\$ 82,624.85$ & $\$ 83,605.43$ & 980.58 \\
\hline
\end{tabular}

* Actual allotment made. 
of the workers for helping people.

The budget for 1944 also showed by source, the actual income for 1942 and 1943, the estimated income for 1943 and 1944, and the differences between the estimated income for 1944 and the actual income for 1943. Those flgures are shown in Table 22.

TABLE 23

TOTAL, RELIEF, AND SALARY EXPENDITURES OF THE FAMILY SERVICE ORGANIZATION FOR EVERY TENTH YEAR BEGINNING WITH 1893

$\begin{array}{lrrr}\text { Year } & \begin{array}{c}\text { Total } \\ \text { Expenditures }\end{array} & \begin{array}{c}\text { Rellef } \\ \text { Expenditures }\end{array} & \text { Salarles } \\ 1893 & \$ 5,039.90 & \$ 2,308.66 & \$ 2,131.00 \\ 1903 & 3,010.30 & 373.52 & 2,236.00 \\ 1913 & 14,736.20 & 6,607.19 & 4,715.30 \\ 1923 & 85,572.90 & 36,167.23 & 39,352.23 \\ 1933 & 284,659.61 & 208,501.65 & 61,343.80 \\ 1943 & 82,624.85 & 31,805.48 & 43,902.50\end{array}$

Table 23 and Chart VII show the total, rellef, and salary expenditures for every tenth year beginning with 1893. As stated, the auditors' reports from 1913 were the source of the amounts and figures used. As the audit for the year 1943 had not been completed, that year was not included in the study, except in Table 23 and Chart VII in which the agency's figures for 1943 were used to complete the presentation. An interesting fact noted in the table was the similarity 
CHART VII

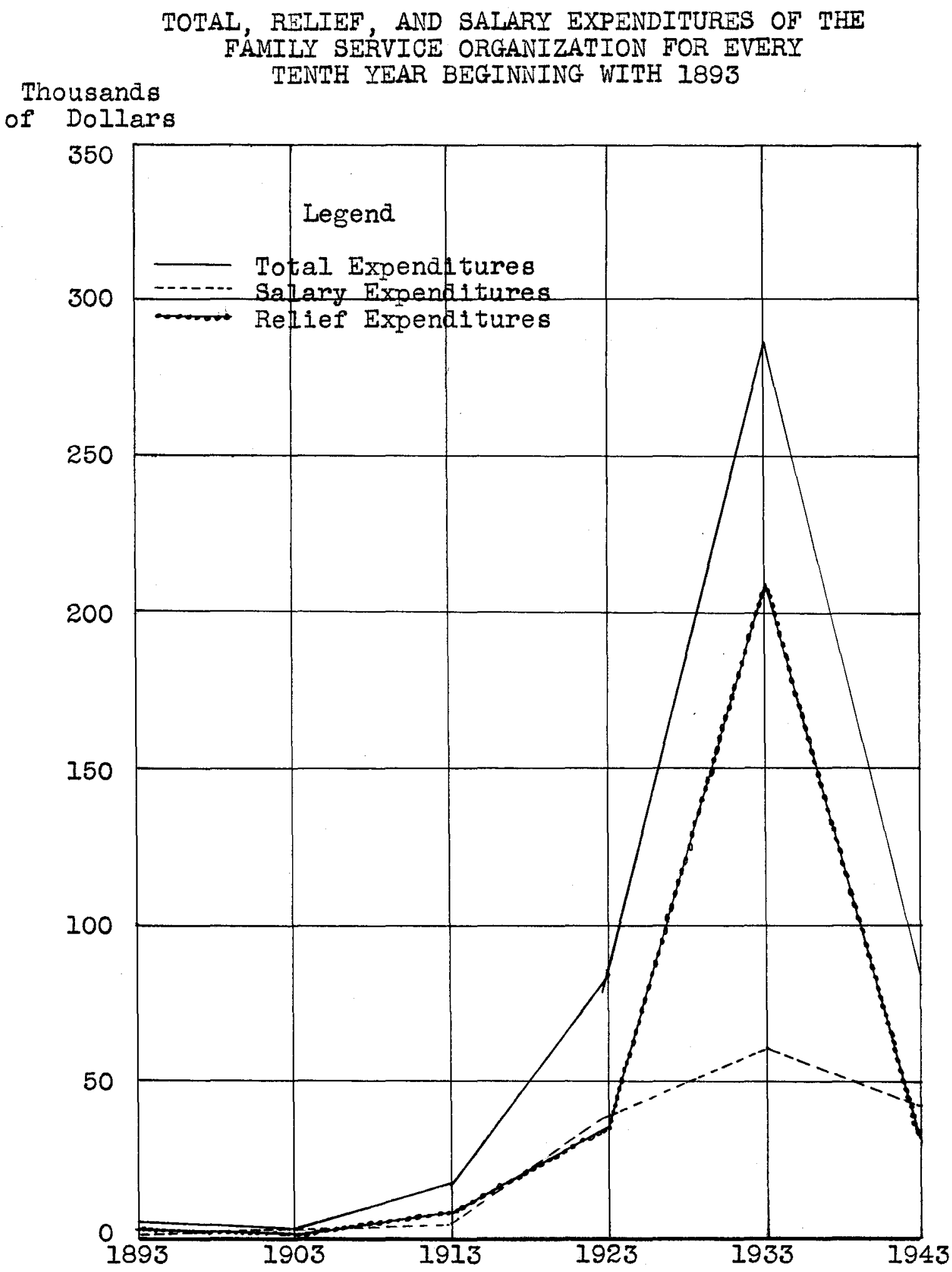


In the figures for 1943 and 1923, the tenth year after and the tenth year before the "depression" year of 1933. Obviously, there were fluctuations within each of the decades presented, but the trends were indicated in the table and chart.

Publicity and Interpretation to the community during the period were varied. In the early years of the depression, the relief need was paramount. PubIlclty to secure adaitional funds and to induce more contributions to the Community Chest resembled publicity of earlier perlods and appealed to the enotions of the public. Headines in the papers were indicative of the type of interpretation needed at the time. Although the agency and the Chest felt such publicity was not desirable; nevertheless, the need for funds was imperative, and it was necessary to present actual facts of sufferIng and inadequacy of relief to the public. Typical of such headlines were: "Cold Snap Drives Many to Ask Aid of City Charities. Forty in line as Family Service Organization opens; Police Stations shelter others." "Worthy Poor to be Given Coal".

As the emergency need was met and much of the suffering was alleviated, the publicity given was of a transitory nature. A few years later, the appeal was still to the public's emotions for financial help, but further explanation of the agency's services was given. Typical headines included: "City's Needy Familles are 
Helped by Chest Agency. Not existence, but an adequate life is Loulsville's responsibility to groups like this, Family Service Organization says." A picture of a poor family in need of help accompanied the article. "Family Service Organization Case Worker is Specialist in Human Needs." "The Family Service Worker looks far beyond giving immediate relief and strives to restore her charges to their origlnal status as self-sustaining, self-respecting citizens." A illustrative picture appeared.

In 1939 , a survey was made by the Community Chest of all the member agencies. One of the results of the survey, which complemented a contemporaneous effort by the agency, was the formation of a commlttee of the agency on interpretation. That committee produced a poster which was intended to reach prospective clients. The poster, accompanied by a letter, was sent to schools, churches, and commercial and industrial establishments. The poster was indicative of a new psychological approach to the public. Previously, all pictures had been of famliles who appeared elther poverty-stricken, 11l, or in suffering of some kind. This poster showed a family of a father, a mother, and two children, all healthy and happy. The caption which accompanied the picture was in the form of a question, "Are you a happy family?" Under the plcture were listed the services which 
the agency offered which helped one to become happier. The poster received special mention from a national organization as an outstanding interpretative poster.

At that time, movies produced by the Family Welfare Association of America were shown in Loulsville, which stressed the work and function of a private family agency.

In general throughout the country, private agencies as well as public agencies, were keenly aware of the necessity of continuous interpretation in contrast to the publicity theretofore made immediately before the Community Chest campaign. Most of the publicity was guided by current practice in journalism and advertising. Material was concise and brief. Pictographs and pictorial charts replaced statistical tables. Some of the popular methods incluaed the newspaper, movies, plays, raaio, meetings, and informal personal contacts. The radio, primarily a source of entertainment rather than education, required material that was adaptable to brief, informal, or dramatic presentation. In 1941, the Family Service Organization presented a play "Then and Now". The play was a skit based on the history of the agency, but presented in an entertaining manner.

One of the sources of income of the private agency was bequests and endowments. They varied in importance in private agency financing. A few agencies 
in the country had large endowments, the annual income from which was sufficient to cover operating costs. In social work, generally, the proportion of income from invested funds to the income from annual contributions was not very large. "Endowments vary almost in direct ratio to the history and age of the locality. The further west, the thinner the endowment deposits." 1

Endowment and bequest funds, the income from which helped defray the operating costs, gave an agency stablity and permanence, and lessened the problem of raising periodical contributions. The danger was the possibility that the endowment funds could become so great the income therefrom would be adequate to meet the agency's needs; the agency might then cease to develop other resources of support, resulting in the agency becoming unresponsive to the public need since it would not be answerable to the public in annual appeals for funds. There was also danger that an "endowed" agency might outlive its usefulness, yet because of its endowments, continue frultless activity.

Donors of funds more recently consider putting bequests or gifts into hands of trustees who can change recipients of funds, If necessary, or leave to a Community Trust or Foundation which has large discretionary powers in use of funds. Endowment funds are of value to an agency when it becomes aware of the need for new activities and the im-

I"Financing Social Work", Soclal Work Year Book, 1933, p. 179 . 
portance of changing the nature of the organization and the use of its endowment funds when the community needs and the methods of meeting these needs change. Endowment funds are of value when the agency is alert to its responsibilities, and not let endowments become a curse. 1

Foundations and trusts were a later development. Only a small part of the income from such funds was used for adrinlstering social agencles. Generally, the bulk of the income from such funds was used in subsidizing research and experimentation. Many of the functions, however, were developed by social agencies.

The Family Service Organization from time to time received sums of money through bequest or gift. The entire principal sum was as follows:

$$
\begin{array}{ll}
\text { Endowment principal } & \$ 15,534.83 \\
\text { Bequests principal } & 13,506.52 \\
\text { Total } & \$ 29,041.35
\end{array}
$$

Over a period of time, the Board of Directors of the agency approved the use of $\$ 9,035.60$ of the princlpal amount from undesignated bequests for the following:

Adaitional relief during depression $\$ 5,200.00$

Research Work

Records system

Total

$$
\begin{array}{r}
1,835.60 \\
2,000.00 \\
\$ 9,035.60
\end{array}
$$

The Family Service Organization had a Special Fund which was started in 1929 made up of specific funds given by interested donors for specific purposes. A

$I_{\text {Elwood Street, Social Work Administration, (New }}$ York: Harper \& Brothers, 1931), p. 415. 
large part of the fund was specific gifts designated to certain families or individuals. Clients, themselves, or relatives of clients often gave money to this fund, and asked the agency to dispense the money for the benefit of the client.

The "Veech Fund", named for Bethel Veech who In administering the bequest of Mary $P$. Gill designated the agency a beneficiary of the bequest, was used specifically for milk and clothing. That bequest produced $\$ 4,000.00$ to $\$ 5,000.00$ per year, and was shared with several agencles.

The "Ix-Convict Fund" was established, in her will, by Lotta Crabtree, a nationally known actress. She designated eight cities, including Loulsville, in which service was to be given ex-convicts.

The "House Fund", before mentioned, was initiated in 1918 after the Family Service Organization became a member agency of the Federation of Social Agencies. The receipts of the fund included rents, income from investments of the specific funds, and other income. All money recelved by this fund was used for the maintenance of the bulldings owned by the Family Service Organization. In addition to the main bullding located at 215 East Walnut Street which housed the agency, the Jewish Welfare Federation, and the Social Service Exchange, the agency owned the building on the rear of that lot, formerly used by the Wayfarers' Lodge, and thereafter rented. 
In 1930, the agency purchased a bullding in the Portland area for use by its Portland District office. Since 1939, after the office was discontinued, the building was rented. About 1934, the House Fund was overdrawn about $\$_{p} 10,000.00$. Through able management, the overaraft was changed to a surplus. From the proceeds of this Fund, the quarters of the agency were remodeled. Offices were sound-proofed and made attractive. Such improvements increased the effectiveness of the work of the agency. Thus, the House Fund contributed to the services extended by the agency.

At present, a fee system is being inaugurated by the Family Service Organization, to provide opportunity for those financially able to receive the services of the agency but who heretofore were reluctant to utilize the services they felt were malntalned by charity.

Whether this system will provide a substantial revenue for the operation of the agency remains to be seen. However, anticipation of revenue is not the object of the plan. With the country in the midst of a global war, many homes are broken and nerves are stretched to the breaking point. As never before, it is important that a family case work agency maintain high standards of personnel and service.

It seems rather fitting to close this history of finances and publicity with a quotation from an edi- 
torial from the Louisville Courier-Journal on

January 31, 1944:

Even those familiar with the activities of Louisville's oldest social agency, the Family Service Organization, must have been surprised to learn from its annual report that service had been rendered to 10,000 individuals during 1943. Perhaps, too, it seems strange that the number of families assisted in solving their domestic difficulties, the case load, should have increased eleven per cent when employment was to be had at good wages. But family problems are as diverse and numerous as human temperaments and conditions, not simple financial, though complicated by unaccustomed prosperity and by poverty alike, among the lowly as well as at higher levels of society.

War time dispersal has also had a serious effect on home ties. This, of course, accounts for the extraordinary number of individuals helped. The trained staff maintains a close liason with the Red Cross and the draft boards. Generally speaking, the war time function of the Red Cross is to minister to service men and women and their dependents, that of the Family Service organization to keep the famijy unit intact and preserve home Iife.

The work of the organization, naturally, is of the most confidential nature. What its staff is capable of accomplishing is best appreciated by the professional few who come in contact with perplexing aspect of the same problems, doctors, lawyers, ministers, visiting teachers, personnel airectors, heads of institutions, draft boards, and Federal parole and juvenile officers. The history of the Family Service Organization is the key to its character, evolving out of a volunteer charitable group which long ago discovered by practical experience that constructive social service must be directed to the salvation of that primary social unit, the family. And it is not alone among the destitute that disruption of a home can often be averted by understanding guidance. That is why the Family Service Organization now opens the opportunity to applicants who are able and 
prefer to pay a small fixed fee. Otherwise, members of that class who realize

their need could not be reached.

In summary, the period of 1929 through 1942 was one of many changes. The ten-year period, 19291939, included the "ciepression period" or the period of public subsidies. At the beginning of the depression, the Family Service Organization attempted to meet the burden of providing for families in need of relief resulting from increasing unemployment. The agency was the only one to take the responsibility. Pressure was brought upon the city to provide for such families. Finally in 1930, the Municipal Relief Bureau was opened. At first, it operated only part of each year, but after 1933, it remained open the entire year. The Family Service Organization continued to bear part of the responsibility. It was necessary for the city to give grants to the agency for the provision of families which were the city's responsibility. As time passed, certain groups of famliles were transferred to the public agency, later known as the Municipal Bureau of Social Service. The final transfer of such families was made in 1938. After which, the Family Service Organization attacked the problem of re-defining its function and the interpretation of its services to the community. Publicity and interpretation were obviously important because of the need of the public's understanding of the agency 
in order for the agency to render its needed service. Since 1938, the income of the agency was mainly derived from the Community Chest. A small portion of the total income came from other sources, as rents, interest from investments, discounts, and refunds. 
CHAPTER $V$

CONCLUSION 


\section{CHAPTER V}

\section{CONCLUSION}

The financing of social work showed changes when the philosophy underlying soclal work changed. In the early beginnings of charity, assistance was spontaneous or mutual. People lived in simple communities, where everyone knew everyone else. Ald was given when and where it was needed by friends and nelghbors. The question of money-raising was unheard of, and there was no necessity for interpretation or publicity, as friends and neighbors "understood" each other's problems and dificulties.

With the advent of the Industrial Revolution and the massing together of people in large cities, the old neighborliness broke down. People were strangers to each other, and distinct barriers arose between the soclal classes. Extremes in poverty and wealth became known. The wealthy tried to gain prestige by assuming a benevolent attitude toward the poorer groups. This so-called charity gave rise to chaos and confusion.

In an attempt to bring order out of chaos, there came into being the Charity Organization Societies, whose purpose was to attack the causes of poverty, to disclose cases of fraud, and to prevent duplication. 


\section{4}

The Louisville Charity Organization Society, incorporated in 1884, was established for that purpose. Money for financing the agency was raised by direct appeal to the public. The philosophy of the period was negativistic and repressive. The people who gave did so in order to expose fraud and prevent duplication. Emphasis was placed on the "worthy" and "unworthy". There appeared to be no degree between the two. If a person was found to be "worthy", he was referred to an individual or soclety which gave ald. The "work house test" was utlilzed to determine the "worthiness" of the unemployed. At first, funds raised for the Charity Organization Society were used only for administrative purposes. No relief was given, and all visiting was done by "friendiy visitorg", who donated their services. By the end of the nineteenth century, some changes became apparent. The Charity Organization Society found it necessary to give emergency relief pending investigation. Relief, therefore, became a service of the Society. Relief funds were raised by the case method. Presentation of a particular family brought funds for the relief of that family's financlal difficulties.

The beginning of the twentieth century brought with it an awareness of paid trained workers to replace the "friendly visitors". Schools of social work were established. Social work evolved into a profession. The philosophy changed from a negative to a more posi- 
tive one. Co-operation was emphasized, and the Louisville Charity Organization Society changed its name to Associated Charities, which reflected more appropriately its philosophy.

Investigations continued to be made, but with the purpose of learning the cause of the "disease". Poverty was considered a "disease". Trained workers were needed to ascertain the causes. The "friendly visitor" frequently allowed her sympathy to dominate her work instead of dolng what was best for the family In her charge. Relief was considered necessary for the treatment of the client.

Money continued to be raised by voluntary subscriptions. Case presentations were utilized, but funds were given to the Society to dispense for families which needed it and not for any particular family. During that period, a big step forward was made in moneyraising. As an out-growth of Worla War I and its War Chests, there came into being a system of federated or joint financing. The Louisville agency was instrumental in instigating the Loulsville Federation of Social Agencies which was organized in 1917, later known as the Welfare League. Federated financing was the method by which a number of agencies grouped together for the purpose of utilizing one campaign of money-raising for the financing of all. Although there were some disadvantages, this system proved to be successful. It was during this 
time, that the agency became more business-like. In 1913, the first audit was made of the books of the agency. Since then, all the books have been kept accurately in contrast to the earlier haphazard and. sometimes inaccurate methods.

In 192I, the agency changed its name to the Family Service Organization. The name carried a greater implication of 1ts function as one of service. Emphasis was placed on prevention, but the approach was a positive one. Service was given on a constructive basis. Trained workers were considered a necessity in order to perform such services to clients as were needed. To assist the workers in increasing their training, opportunity was given for further study at universities.

Support was primarily through the Community Chest, formerly the Welfare League. The Community Chest tended to regulate the bookkeeping of the various affiliated agencies. Budgets became of paramount importance. A presentation to the Community Chest of the agency's budget was a prerequisite for an allotment to the agency. Great time and effort was expended in the preparation of the buaget and its presentation.

During the $1920^{\prime} \mathrm{s}$, unemployment and financial stress increased. The private family agency was the only one qualified to assume the responsibility. In 1929, the "stock market crash" precipitated the greatest 
depression in the world's history. The load on the agency approached the unbearable; casework standards and personnel stancards were lowered; and all efforts were for the alleviation of the emergent needs of material relief. Relief, itself, was inadequate, and provided the families only sub-subsistance. Through efforts of the Family Service Organization and the Community Chest, the city government recognized its responsibility. Subsidies were granted to the agency, and In 1930, the Municipal Relief Bureau was opened. At first, it operated only part of the year and assumed only partial responsibility. As time passed, more and more of the cases of public responsibility were turned over to the public agency, later known as the Municipal Bureau of Soclal Service. By 1938, the transfer of all such families to the public agency was completed.

During the depression period, the agency had to and did curtail many of its services. In the transition years of 1938 and 1939, a re-defining of function was necessary, and a great deal of public1ty and interpretation was needed for the public. People had grown accustomed to thinking of the agency as a relief agency, particularly since most of the appeals for more than a decade had been for relief.

With this period of transition, a new approach was used. Emphasis was placed on the more positive as- 
pect. Prevention, seen in earlier years, was still the key word. Publicity stressed the importance of keeping one happy and well-adjusted. Prevention of family and indiviaual breakdown was as much case work treatment as was the rehabilitation of a family or the adjustment of a personality difficulty.

Throughout the study, the effort has been to reveal the relationship between financing, publicity, and a highly trained personnel; financing is dependent upon the latter two. Funds cannot be secured for the financing of the agency unless the public is aware of the work of the agency. The public will not realize the value of the agency's service unless its work is of the highest caliber and positive results are seen. Success of any social agency in securing the required funds from year to year depends upon the good will of the community. The respect and esteem in which the organization is held by the community varies with the value the community attaches to the agency's work. Although trained personnel may cost more in terms of dollars, the real value of the services rendered is to be measured by the results achieved rather than only by the money spent. 
BIBLIOGRAPHY 
BIBLIOGRAPHY

\section{Books}

Colcord, Joanna. Emergency Work Rellef. New York: Russell Sage Foundation, 1932.

Gerlinger, Irene Hazard. Money Raising - How To Do It. New York: Kellaway-Ide Co., 1938.

Intelligent Philanthrophy. Edited by E. Faris, F. Laune and A. Todd. Chicago: The University of Chicago Press, 1930.

Proctor and Schuck. Financing of Social Work. Chicago \& New York: A. W. Shaw Co., I926.

Steiner, Jesse F. Community Organization. New York: The Century Co., 1925.

Street, Elwood. Soclal Work Administration. New York: Harper and Brothers, 1931.

Warner, Amos G. American Charities. New York: Thomas Y. Croweli Co., 1919 .

Warner, Queen and Harper. American Charities and Social Work. New York: Thomas Y. CrowelI Co., 1930 .

Watson, Frank D. Charity Organization Society Movement in the United States. New York: McMillan \& Co., 1922.

\footnotetext{
Articles

Clapp, Raymond. "Welfare Federation of Cleveland", Proceedings of the National Conference of Soclal Work, 1922.
} 
Kelso, Robert. "Community Chest and Relief Giving", Proceedings of the National Conference of Soc1al Work, 1930.

Linderholm, Natalie. "Publicity and Interpretation in Social Work", Social Work Year Book, 1939.

Lurie, H. L. "Financing Private Social Work", Social Work Year Book, 1939.

Rantzahn, Mary S. "Avallable Channels of Publicity", Proceedings of the National Conference of Soclal Work, 1926.

Social Work Year Book. 1929. Article, "Community Chests and Councils".

Social Work Year Book. 1933. Article, "Financing Social Work".

Swift, Linton B. "The Chest and the Family Soclety", The Family, July, 1925 .

\section{Unoublished Material}

Bateman, Milared. "Lay Participation in the Private Family Agency, Louisvilie, Kentucky". Unpublished Master's thesis, Division of Social Administration, University of Louisville, 1941.

Ellis, Bernice. "History of the Family Service Organization". Unpublished Master's thesis, University of Chicago, 1941.

"1917-1940. Community Chest of Louisville and Jefferson County. Twenty-three years of Service". On file at Communty Chest.

Prinz, Marian E. "A Study of the Family Service Organization, Loulsville, Kentucky, In Reference to Intake". UnpubI1shed Master's thesis, D1v1sion of Social Administration, University of Louisville, 1941.

Taylor, Esther M. "Ten-Year Study. 1927-1936". On file at the Famlly Service Organization.

"The First Twenty-five Years, 1917-1942". Report made at the annual meeting of the Community Chest, March 9, 1943. 
"The Ninetieth Year", pamphlet by the Welfare League, 1921.

\section{Miscellaneous}

Material on file at the Family Service Organization: Annual Reports

Budgets

Financial papers

Minutes of meetings of Board of Directors

Newspapers 